УДК 621.3

С.П. Денисюк, д-р техн. наук, проф. ORCID 0000-0002-6299-368

B.A. Таргонський, магістрант ORCID 0000-0003-3801-8284

Національний технічний університет України «Київський політехнічний інститут імені Ігоря Сікорського»

\title{
СТАЛИЙ РОЗВИТОК ЕНЕРГЕТИКИ УКРАЇНИ У СВІТОВИХ ВИМІРАХ
}

У статті розглянуто особливості сталого розвитку світової енергетики, дана характеристика ініціативи "Стала енергетика для всіх» (Sustainable Energy for All, SEforAll). Наведено оцінку впливу розвитку енегетики на сталий розвиток економіки в иілому та на кліматичні зміни в рамках положень Паризької кліматичної угоди. Для оиінки напрямків розвитку енергетики Украӥни в ХХІ ст. представлено європейські орієнтири. Детально проаналізовано стан виконання вимог сталого розвитку в украӥнському паливно-енергетичного секторі у відповідності до Цілі сталого розвитку № 7 та основних завдань національних директивних документів.

Для аналізу перспектив розвитку національного паливно-енергетичного сектору проаналізовано показники енергетичної трилеми (енергетична безпека, енергетична рівність, екологічна стійкість), запропонованої СЕР, для Украӥни та окремих країн світу. Для комплексної характеристики окремих секторів паливно-енергетичного комплексу Украӥни здіснено співставлення показників Украӥни та окремих країн як за даними Всесвітнього банку даних Enerdata Yearbook, зокрема, динаміки зміни енергосмності, споживання та виробництво енергії у 1990-2016 роках, а також за даними Wоrld Development Indicators y 2016 p. Охарактеризовано стан України за результатами 2016 . за даними Wогld Economic Forum згідно Global Energy Architecture Performance Index за такими показниками як економічне зростання і розвиток, екологічна стійкість, енергетичний доступ і безпека.

Ключові слова: сталий розвиток, стала енергетика для всіх, енергетична трилема, енергоємність, споживання та виробництво енергіï, Enerdata Yearbook, Global Energy Architecture Performance Index.

Вступ

Енергія є основою забезпечення промислового виробництва, надання послуг в транспортній сфері, функціонування житлово-комунального господарства, створення сприятливих умов для життєдіяльності населення, а енергетика - галузь, що в значній мірі визначає рівень соціально-економічного розвитку країни $[5,9,13,15-22]$. Важливим пріоритетом розвитку енергетики на довгострокову перспективу повинна стати мінімізація ризиків: економічних, соціальних, екологічних, що має додати стійкість розвитку енергетики і всієї економіки нашої країни. У світі екологічний фактор стає все більш важливим пріоритетом для формування нової економіки, модернізації, технологічного оновлення, що і визначає необхідність переходу до сталого розвитку та «зеленої» енергетики, структурно-технологічної модернізації та трансформації українського енергетичного сектора $[2,8,13]$.

У значній мірі розвиток як світової енергетики, так і енергетики України, у першій половині XXI ст. буде визначати Паризька кліматична угода ООН (прийнята в Парижі консенсусом 12 грудня 2015 р. та підписана 22 квітня 2016 р.). Метою Паризької кліматичної угоди (відповідно до статті 2) є «активізувати здійснення» Рамкової конвенції ООН зі зміни клімату, зокрема, утримати зростання глобальної середньої температури «набагато нижче» $2^{\circ} \mathrm{C}$ «докласти зусиль» для обмеження зростання температури величиною $1,5^{\circ} \mathrm{C}[1,4,5,7,9]$. Важливо оцінити розвиток енергетики України згідно вимог сталого розвитку. Використання різних світових оцінок надасть можливість об'єктивно проаналізувати теперішню ситуацію і розглянути подальші перспективи розвитку енергетики України згідно вимог сталого розвитку .

Сталий розвиток енергетики: сутність та методичні підходи до оцінки

Термін «сталий розвиток» (sustainable development) набув широкого поширення у 1987 р. після того, як Міжнародна комісія з навколишнього середовища і розвитку ООН (комісія Гро Гарлем Брундтланд) опублікувала доповідь «Наше спільне майбутнє». У цій доповіді сталий розвиток визначається наступним чином: «Людство здатне надати розвитку сталий і довготривалий характер з тим, щоб він відповідав потребам нині живих людей, не позбавляючи майбутні покоління можливості задовольняти свої потреби.ц Сталий і довготривалий розвиток являє собою не незмінний стан гармонії, а скоріше процес змін, в якому масштаби експлуатації ресурсів, напрямки капіталовкладень, орієнтація технічного розвитку та

(C) С.П. Денисюк, В.А. Таргонський, 2017 


\section{ISSN 1813-5420 (Print). Енергетика: економіка, технології, екологія. 2017. № 3}

інвестиційні зміни узгоджуються 3 нинішніми і майбутніми потребами» $[1,3,7,13]$. Сталий розвиток енергетики є однією з цілей сталого розвитку економіки в цілому. Сталий розвиток енергетики прийнято характеризувати в розрізі економічної, екологічної та соціальної компоненти. Його доцільно розглядати на 3 рівнях: 1) на рівні держави; 2) на рівні галузей енергетики; 3) на рівні підприємств енергетики $[4,5,9,13]$.

Сталий розвиток енергетики держави являє собою здатну до саморегулювання систему забезпечення енергетичної безпеки з урахуванням оптимізації територіальної структури виробництва i споживання ПЕР при підвищенні самостійності регіонів у вирішенні питань енергозабезпечення, включаючи контроль за раціональним використанням енергоресурсів, енергозбереження, виробництвом теплової та електричної енергії, а також пошук нових способів автономного задоволення потреб промисловості та населення регіон в енергії. Центральним у цьому розумінні сталого розвитку енергетики держави $є$ забезпечення енергетичної безпеки країни.

Доцільним у подальшому також $\epsilon$ розгляд сталого розвитку галузей енергетики як процесу технологічного та економічного їх розвитку в невизначених умовах, спрямованого на надійне i безперебійне енергопостачання споживачів при раціональному використанні ресурсів і мінімальному впливі на навколишне середовище з метою підвищення ефективності функціонування регіону. У свою чергу, сталий розвиток підприємств енергетики - це процес технологічного та економічного їх розвитку в невизначених умовах, спрямований на досягнення їх стратегічних цілей при підвищенні задоволеності замовників, виконання зобов'язань перед різними контрагентами та мінімальному впливі на довкілля 3 метою підвищення ефективності функціонування галузей енергетики та регіональної економіки.

У 2000 році Декларацією Тисячоліття ООН (затвердженою резолюцією № 55/2 Генеральної Асамблеї від 8 вересня 2000 року) було визначено орієнтири глобального розвитку до 2015 року - Цілі Розвитку Тисячоліття. Ріо-де-Жанейрська Декларація по навколишньому середовищу i розвитку задекларувала, що «Стала енергетика - енергетика, вироблена і використовувана на шляху, який підтримує людський розвиток в довгостроковій перспективі у всіх його економічних, соціальних та екологічних аспектах» (прийнята Конференцією ООН по навколишньому середовищу і розвитку, Ріо-де-Жанейро (Бразилія), 3-14 червня 1992 року).

326 серпня по 4 вересня 2002 року в Йоганнесбурзі (ПАР) відбулася Всесвітня зустріч на вищому рівні зі сталого розвитку, яка оцінила досягнення, а також зміни та появу нових проблем після зустрічі на вищому рівні «Планета Земля» у 1992 році. Цей саміт трансформував мету, обіцянки і зобов'язання «Agenda 21» в конкретні та практичні дії. На саміті «Планета Земля» визначено, що стратегія розвитку сталої енергетики - розробка політики, що заохочує розвиток енергетики і технологій, заснованих на відновлюваних джерелах енергї̈ (ВДЕ) та більш чистих видах викопного палива; розробка програм, що підтримують енергоефективність та використання відновлюваної енергії $[4,9,12,23]$.

Глава ООН Пан Гі Мун (Ban Ki Moon) у вересні 2011 році виступив з ініціативою «Стала енергетика для всіх» (Sustainable Energy for All, SEforAll). «Стала енергетика для всіх» (далі - SEforALL ) - ініціатива Генерального Секретаря ООН та Президента Світового Банку Джим Юн Кім (Jim Yong Kim). Нову глобальну ініціативу розпочала здійснювати координаційна група у складі 20 установ системи ООН «OOH-енергетика», очолювана Генеральним секретарем ООН Пан Гі Муном. Ініціатива SEforALL народилася з усвідомлення необхідності змін, оскільки в Декларації тисячоліття була відсутня мета в області розвитку енергетики, виникла певна незадоволеність щодо відсутності розуміння важливості питань енергетики, особливо екологічно чистої енергії. Генеральним секретарем ООН Пан Гі Мун проголошено «Стала енергетика для всіх необхідна і досяжна. Ми повинні побудувати нове енергетичне майбутне, засноване на пануванні технологій і інновацій, поставлених на службу людям і планеті. Стала енергетика для всіх є благом для економіки та довкілля, вона також сприяє більшій справедливості в глобальному масштабі. Це шлях, що веде в майбутнє» [1].

Глобальна ініціатива SEforALL спрямована на досягнення до 2030 року трьох основних цілей $[1,5$, 9, 23]: забезпечення повсюдного доступу до сучасних енергетичних послуг; зниження світового споживання електроенергії на 40\%; збільшення частки ВДЕ в світі до $30 \%$. Ініціатива SEforALL передбачає революційні та еволюційні заходи, спрямовані на реформування системи використання джерел енергії. У рамках цієї ініціативи експерти визначили як щорічно мобілізувати 120 млрд. дол. для розвитку сталої енергетики. Експерти Світового банку вважають, що для реалізації ініціативи SEforALL необхідно в три рази збільшити інвестиції в сферу енергетики (до 1,25 трлн. дол. США).

У своій резолюції А 65/151 від 4 грудня 2011 р. Генеральна Асамблея ООН на знак визнання важливості енергетики для сталого розвитку постановила проголосити 2012 рік «Міжнародним роком сталої енергетики для всіх». Асамблея рекомендувала всім державам-членам ООН скористатися проведенням Року для підвищення рівня обізнаності про важливість вирішення питань, пов'язаних із забезпеченням сучасного енергопостачання, доступом до недорогих енергоресурсів, енергоефективністю та екологічністю джерел енергії.

У січні 2012 року Генеральний секретар ООН Пан Гі Мун представив Генеральній Асамблеї 
п'ятирічну програму дій, що має назву «Майбутнє, якого ми прагнемо», яка являє собою план, покликаний сприяти побудові більш безпечного, більш надійного, більш стійкого і більш справедливого майбутнього. Пан Гі Мун визначив «сталу енергетику для всіх в якості одного з головних пріоритетів, оскільки вона $\epsilon$ центральним елементом всіх аспектів сталого розвитку». У цьому ж місяці Група високого рівня 3 глобального сталого розвитку під керівництвом Чарльза Холлідея та Кандех Юмкелла, у своїй доповіді під назвою «Життєздатна планета життєздатних людей: майбутнє, яке ми вибираємо» схвалила ініціативу SEforALL і заявила, що іiі необхідно негайно втілити в життя.

Розроблена програма «Стала енергетика для всіх: Глобальна програма дій» затверджена резолюцією ООН А / 67 / 175 від 31 липня 2012 р. У Глобальної програми дій визначені 11 сфер діяльності, спрямованих на досягнення трьох зазначених цілей SEforALL. Сфери діяльності охоплюють сім «секторальних» областей: а) сучасне кухонне обладнання і види палива; b) раціональні варіанти розподілу електроенергії; c) інфраструктура та ефективність електроенергетичних систем; d) великомасштабні відновлювані джерела енергії; е) промислові та сільськогосподарські процеси; f) транспорт; g) будівлі та побутові прилади. $€$ також чотири «допоміжні» області діяльності: а) планування та стратегії у сфері енергетики; b) бізнес-модель і технологічні інновації; с) фінансові ресурси і регулювання ризиків; d) зміцнення потенціалу та обмін знаннями.

Як глобальна платформа, SEforALL надала змогу лідерам здійснювати партнерські відносини та розгортати фінансування для досягнення загального доступу до стійкої енергії як внесок у створення більш чистого, справедливого і процвітаючого світу для всіх. Розроблена серію «теплових карт», які показують, де відбувається прогрес, щоб була можливість відтворити успіх інших і допомогти лідерам уряду, бізнесу та громадянського суспільства зробити правильний вибір.

У 2012 році на Конференції ООН зі сталого розвитку Ріо+20 «Майбутнє, якого ми прагнемо» (відомої як Саміт «Ріо + 20», що відбувся 20-22 червня 2012 році в Ріо-де-Жанейро (Бразилія)) питання майбутнього розвитку було включене у підсумковий документ у формі запиту до Генеральної Асамблеї ООН щодо створення міжурядової Робочої групи для внесення пропозицій щодо нових цілей - Цілей сталого розвитку (ЦСР). У підсумковому документі визначено, що формулювання ЦСР має бути узгоджено $з$ Цілями Розвитку Тисячоліття та 3 процесом формування «Порядку денного в галузі розвитку після 2015 року». На Конференції ООН зі сталого розвитку держави домовилися створити відкриту робочу групу для розробки комплексу Цілей сталого розвитку.

Підсумковий документ під назвою «Майбутне, якого ми прагнемо» схвалено цією конференцією та прикладено до Резолюції 66/288 Генеральної Асамблеї ООН від 11 вересня 2012 р.). Цей документ визначає важливу роль енергії в процесі розвитку, оскільки доступ до сталих сучасних енергетичних послуг сприяє викоріненню бідності, рятує життя, покращує здоров'я і допомагає забезпечити задоволення основних людських потреб [1]. У резолюції № 66/288 «Майбутнє, якого ми прагнемо» зазначено, що підвищення енергоефективності, збільшення частки ВДЕ та перехід на більш екологічно чисті та енергоефективні технології мають важливе значення для сталого розвитку, в тому числі для боротьби зі зміною клімату. Визнано необхідність вжиття заходів щодо забезпечення енергоефективності в ході міського планування, при експлуатації будівель і транспорту, а також при виробництві товарів і послуг та розробці нової продукції. Зазначено важливість пропаганди стимулів для підвищення енергоефективності та диверсифікації джерел енергії, а також усунення перешкод у цій сфері, утому числі шляхом надання сприяння відповідним дослідженням і розробкам.

Резолюція № 67/215 «Сприяння розширенню використання нових та відновлюваних джерел енергії», прийнята Генеральною Асамблеєю 21 грудня 2012 року, постановляє оголосити 2014-2024 роки «Десятиліттям сталої енергетики для всіх» ООН для сприяння реалізації цієї концепції стосовно всіх джерел енергії, беручи до уваги положення додатка до резолюції 1980/67 Економічної і Соціальної Ради від 25 липня 1980 року та підкресливши важливість сучасних послуг у сфері екологічно сталого енергопостачання для ліквідації бідності та розвитку в цілому.

У жовтні 2013 року засновано Копенгагенський центр з питань енергоефективності (The Copenhagen Centre on Energy Efficiency - C2E2). C2E2 слугує центром енергоефективності ініціативи генерального секретаря ООН з питань сталого енергозабезпечення для всіх (the Energy Efficiency Hub of the UN Secretary General's Sustainable Energy for All) та відіграє провідну роль у просуванні однієї з цілей - подвоїти рівень підвищення енергоефективності до 2030 року. С2Е2 сконцентрував зусилля на роботі в регіонах із залученням місцевих партнерів до проведення аналізу та здійснення огляду застосовуваних заходів політики щодо підвищення енергоефективності, відповідних пріоритетів і можливостей в ключових країнах Африки, Азії, Східної Свропи, Кавказу, Середньої Азії та Латинської Америки.

У 2014 році на сесії Генеральної Асамблеї ООН в узагальненій доповіді «Дорога до гідного життя до 2030 року: викорінення бідності, перетворення умов життя всіх людей та захист планети» представлено основні положення щодо цілей розвитку на наступний програмний період. У липні 2014 року робоча група Генеральної Асамблеї ООН по цілям сталого розвитку схвалила документ, що містить ряд екологічних, економічних і соціальних завдань, спрямованих на досягнення сталого розвитку. 


\section{ISSN 1813-5420 (Print). Енергетика: економіка, технології, екологія. 2017. № 3}

У вересні 2015 року в рамках 70-ї сесії Генеральної Асамблеї ООН у Нью-Йорку відбувся Саміт ООН з прийняття Порядку денного розвитку після 2015 року, на якому було затверджено нові орієнтири розвитку. Підсумковий документ «Перетворення нашого світу: порядок денний у сфері сталого розвитку до 2030 року» було затверджено 25 вересня 2015 року на відкритті цього Саміту ООН.

25 вересня 2015 року 193 держави-члени ООН на Саміті зі сталого розвитку в Нью-Йорку одностайно прийняли нову глобальну програму сталого розвитку (початок реалізації з 1 січня 2017 р.). Резолюція Генеральної Асамблеї ООН «Перетворення нашого світу: Порядок денний розвитку у галузі сталого розвитку на період до 2030 року» визначає 17 цілей сталого розвитку (ЦСР) з 169 цільовими показниками, на противагу попереднім восьми цілям розвитку тисячоліття, які передбачали досягнення 21 цільового показника $[7,8]$. Це стало початком роботи з формулювання нових цілей розвитку на наступні п’ятнадцять років - до 2030 року. ЦСР відображають масштаб та спрямування нового порядку денного, а також враховують незавершені питання Цілей розвитку тисячоліття. ЦСР є всеохоплюючими та неподільними, вони враховують три аспекти сталого розвитку: економічний, соціальний та екологічний. При цьому ЦСР слугують орієнтирами для встановлення цілей на національному рівні та моніторинговим інструментом для вимірювання суспільного прогресу у 193 країнах світу.

3 точки зору енергетичного сектора для нас важливо проаналізувати ЦСР7 - Ціль 7. Забезпечення доступу до недорогих, надійних, стійких і сучасних джерел енерzії для всіх. Ціль 7 має наступні підцілі:

7.1. До 2030 року забезпечити загальний доступ до недорогого, надійного i сучасного енергопостачання;

7.2. До 2030 року значно збільшити частку енергії з відновлюваних джерел у світовому енергетичному балансі;

7.3. До 2030 року подвоїти глобальний показник підвищення енергоефективності;

7.а. До 2030 року активізувати міжнародне співробітництво 3 метою полегшення доступу до досліджень і технологій в галузі екологічно чистої енергетики, включаючи відновлювану енергетику, підвищення енергоефективності та передові й більш чисті технології використання викопного палива, та заохочувати інвестиції в енергетичну інфраструктуру і технології екологічно чистої енергетики;

7.b. До 2030 року розширити інфраструктуру і модернізувати технології для сучасного та сталого енергопостачання всього загалу у країнах, що розвиваються, зокрема у найменш розвинених країнах, малих острівних державах, що розвиваються, і країнах, які не мають виходу до моря, з урахуванням їх відповідних програм підтримки.

Власне ЦСР7 прийнята на тлі серйозного дисбалансу в розвитку світової енергетики: понад мільярд людей на планеті не забезпечені електроенергією в достатньому обсязі, а потенціал підвищення ефективності енергоспоживання будівель, транспортної системи і виробничих процесів залишається в значній мірі неосвоєних. Експерти визначили, що коли ЦСР7 не буде досягнута, буде вкрай складно забезпечити доступ до якісної охорони здоров'я і освіти, гендерна рівність, нові робочі місця, економічне зростання, сталий споживання або ефективну боротьбу зі змінами клімату, які ставлять під загрозу досягнення всіх цілей. Наслідком уваги до даної проблематики стала ініціатива SEforALL та Десятиліття стійкої енергетики для всіх Організації Об'єднаних Націй (2014-2024 роки).

Ініціатива SEforALL $є$ потужним інструментом для виконання обіцянок щодо Цілей сталого розвитку та Паризької кліматичної угоди. «Ефективна чиста енергія - це золота нитка, яка пов'язує економічне зростання, збільшення соціальної справедливості та здорового навколишнього середовища» зазначив Пан Гі Мун [1]. Енергія $є$ основою для соціального та економічного благополуччя, однак на сьогодні 1,1 млрд. людей не має доступу до електрики, а 2,9 млрд. мають готувати 3 забруднюючих, неефективних палив, таких як дрова. Без швидкого прогресу в реалізації ЦСР7, який вимагає «доступної, надійної, стабільної та сучасної енергії для всіх», до 2030 року неможливо буде забезпечити досягнення інших цілей сталого розвитку. Одночасно виробництво та використання енергії є домінуючою причиною зміни клімату. Власне термін «глобальне потепління» був запропонований американським геологом $\mathrm{i}$ кліматологом Уоллесом Броекер ще в 1975 році у статті «Зміна клімату: чи ми на порозі різкого глобального потепління?» (журнал Science). У той час ще було не ясно, наскільки великий масштаб цього явища. У 70-ті роки XX ст. цим питанням займалися лише деякі вчені. Однак через чотири десятиліття стало очевидно, що глобальне потепління перетворилося на справжню екологічну проблему, яка викликає як соціальні, так і економічні та політичні наслідки.

\section{Вимоги Паризької кліматичної угоди щодо скорочення викидів парникових газів}

У грудні 2015 року на 21-й конференції сторін рамкової конвенції ООН зі зміни клімату була прийнята нова міжнародна кліматична угода - Паризький договір (на зміну Кіотському протоколу). Угода набере чинності 1 січня 2021 року. Угода є результатом майже десятирічних переговорів в рамках Рамкової конвенції ООН про зміну клімату. Формальне розпорядження розробити протокол, інші правові документи та представити документ, що має юридичну силу і який можна застосовувати до всіх учасників, було прийнято в м. Дурбан в 2011 р. В рамках Дурбанської робочої групи сторони вели переговори по двох взаємозалежних напрямках: Напрямок 1 було пов'язано з переговорами щодо Угоди 2015 року; Напрямок 
2 було націлене на підтримку намірів країн учасників по скороченню викидів шкідливих речовин, поки Угода не набере, як очікується, в силу у 2022 р.

Паризька кліматична угода потенційно накладає на Україну нові зобов'язання із скорочення викидів парникових газів (ПГ). Це безпосередньо впливає на розвиток енергетичного сектора країни як найбільшого джерела викидів парникових газів. Паризька кліматична угода, серед іншого, встановлює ціль щодо утримання глобальної температури на Землі в межах $2^{\circ} \mathrm{C}$ до 2100 року. Однак відповідно до очікуваних національно-визначених внесків (OHBB) країн-підписантів викиди парникових газів цих країн спричинять зростання глобальної температури на рівні $3,5^{\circ} \mathrm{C}$ до 2100 року. На переговорах у Парижі українська делегація озвучила ціль із скорочення викидів на $40 \%$ до 2030 року відносно рівня викидів ПГ 1990 року.

Згідно 3 новою глобальною ціллю Паризької кліматичної угоди $\left(2{ }^{\circ} \mathrm{C}\right)$, у разі припущення пропорційності викидів ПГ до зміни глобальної температури, власне ціль мусить бути скоригована $340 \%$ до $70 \%$ у 2050 році до 1990 року, що може відповідати сценарію утримання глобальної температури в межах $2{ }^{\circ} \mathrm{C}$. Ймовірно, що на наступних кліматичних переговорах Україні запропонують взяти на себе саме такі зобов'язання. Співставлення викидів парникових газів у 1990-2012 роках та майбутні цілі для України (т СО2-екв): 1990 р. - 870,40; 2000 p. $-361,70 ; 2005$ p. - 378,50; 2010 p. $-345,20 ; 2012$ p. - 371,0; 2020 р. - 696,0 (ціль 1 - скорочення $25 \%$ ); 2030 р. - 522,0 (ціль 2 - скорочення 40 \%); 2050 р. - 261,0 (ціль 3 - скорочення $70 \%)$.

Визначено, що енергоефективність та ВДЕ відіграватимуть найважливішу роль у запобіганні підвищення глобальної температури більш ніж на $2{ }^{\circ} \mathrm{C}$ і скорочення викидів $\mathrm{CO}_{2}$ у період до 2050 року.

Наступна кліматична конференція відбулася з 7 по 18 листопада 2016 р. у Марракеші. Близько 15 тис. представників зі 196 країн світу зібрались 7 листопада 2016 р. у марокканському місті Марракеші для обговорення дорожньої карти втілення Паризької кліматичної угоди. «Ми закликаємо до найвищої політичної відданості боротися зі зміною клімату, що є питанням нагального пріоритету», - наголошується у «Марракеській декларації щодо дій» (ухвалено 17 листопада 2016 р.)

6 - 17 листопада 2017 року в Бонні пройшла Всесвітня конференція ООН з питань зміни клімату (СОР23), в якій взяли участь глави держав і представники урядів близько 200 держав (близько 25 тис. представників). Основне питання конференції - розробка конкретних заходів щодо здійснення Паризької кліматичної угоди. 2017 рік може стати одним із трьох найспекотніших з моменту початку спостережень у XIX столітті. Про це на конференції заявив генеральний секретар Всесвітньої метеорологічної організації $\mathrm{OOH}$ (ВМО ООН) Петтері Таалас. За попередніми даними ВМО ООН, через потужний феномен «ЕльНіньйо» 2016 рік, вочевидь, залишиться найтеплішим роком в історії досліджень, а 2017 р. та 2015 p. посядуть друге і (або) третє місця. Період з 2013 по 2017 рік стане найтеплішим п'ятиріччям від початку спостережень, йдеться в попередньому звіті ВМО ООН про стан клімату, оприлюдненому 6 листопада 3 нагоди початку конференції в Бонні.

В рамках заходів конференції Генеральний секретар ООН Антоніу Гутерріш (António Guterres) заявив, що у людства $€$ всього 5 років на те, щоб спробувати утримати підвищення глобальної температури в межах $1,5^{\circ} \mathrm{C}$; для цього вже до 2020 року потрібно скоротити емісії парникових газів хоча б на чверть.

Головним результатом конференції у Бонні став проект документів щодо виконання Паризької кліматичної угоди. Затвердити цей проект планують на наступній кліматичній конференції, яка відбудеться у 2018 році. У проекті правил щодо виконання Паризької кліматичної угоди йдеться головно про те, яким чином 195 держав-учасниць мають вимірювати обсяг викидів $\mathrm{CO}_{2}$ в атмосферу. Усі державипідписанти повинні застосовувати однакові методи вимірювання. 16 листопада 2017 р. 18 держав, а також кілька американських штатів і підприємств (усього 25 учасників) оголосили про створення міжнародного альянсу за відмову від вугільної енергетики.

Американські державні відомства 3 листопада 2017 р. опублікували звіт (обсягом 477 стр.), який вказує на вину людини у глобальних змінах клімату [12]. У звіті зазначено, що «дуже ймовірно, що людський вплив був домінантною причиною потепління, яке спостерігається з середини XX ст. Для потепління впродовж останнього століття відсутні переконливі альтернативні пояснення, які б грунтувалися на доказах, зібраних під час спостережень». Згідно зі звітом рівень моря до 2100 року може піднятися на 2,4 м. Звіт визначає складові шкоди, вже завданої США через глобальне потепління. У звіті також згадуються інші негативні впливи людства на стан довкілля: окислення океанів та забруднення повітря, яке однак дещо скоротилося у 2014 та 2015 роках. Документ було підготовлено за участі сотень учених та державних службовців. Американська Національна академія наук переглянула звіт перед тим, як його було передано 13-м відомствам, які й оприлюднили його. Білий дім не став блокувати публікацію або змінювати текст. Як зазначено в жовтневому звіті за 2017 рік Потсдамського інституту вивчення клімату (РІК) «дестабілізація клімату може привести до дестабілізації суспільства».

Для реалізації глобальної, багатосторонньої платформи SEforALL, яка буде стимулювати дії для ЦСР 7 з врахуванням Паризької кліматичної угоди, розроблено нову п'ятирічну стратегією. Стратегічні рамки для планів на 2016-2021 років під назвою «Ідемо далі, швидше» («Going Further, Faster») було 


\section{ISSN 1813-5420 (Print). Енергетика: економіка, технології, екологія. 2017. № 3}

схвалено 15 червня 2016 року в Брюсселі Консультативною радою зі сталої енергетики, співголовами якої $\epsilon$ Генеральний секретар ООН Пан Гі Мун і президент групи Світового банку Джим Юн Кім. Запропоновано нову систему взаємовідносин, яка сприятиме новому періоду дій та розробці політики для SEforALL, зокрема, вирішенню проблеми подвійного енергетичного виклику: як ми забезпечуємо сучасний, надійний доступ до енергії для всіх, не сприяючи кліматичним змінам?

У лютому 2017 р. Світовий банк опублікував перший узагальнюючий звіт за результатами дослідження RISE - Regulatory Indicators for Sustainable Energy («Показники регулювання сталої енергетики») [16]. У документі порівнюються політики країн в трьох областях: доступ громадян до енергії, енергоефективність і держпідтримка відновлюваної енергетики. Метою звіту є допомога урядам в оцінці того, чи $€$ у них необхідна політична і нормативна база для досягнення прогресу в області сталої енергетики, а також у визначенні напрямків, більш широкого залучення приватних інвестицій.

У дослідження були включені 111 країн, які сукупно становлять 96 \% світового населення і $91 \%$ енергоспоживання. Для оцінки результативності держполітики кожної країн використовувалися 27 індикаторів і 80 підіндикаторів. Абсолютними лідерами сукупно за всіма трьома областям виявилися Данія, США і Канада. Загальний бал України - 67 балів (з 100), вона в рейтингу займає 45 місце - останнє в «середній» зоні. В області енергоефективності лідирують США - 88 балів, далі йдуть Данія та Румунія. Україна тут отримала 37 балів і опинилася на межі зони «нижче середнього». Серед причин такої низької оцінки експерти назвали брак інформації, що надається споживачам; незначимість стимулів до енергозбереження від структури тарифів; мала кількість стимулів до економії у великих підприємств і в комунальній сфері, практично повна відсутність подібних стимулів в держсекторі, недостатня кількість стандартів для мінімального споживання енергії. В області держпідтримки відновлюваної енергетики лідер Данія (94), за нею йдуть Нідерланди та Німеччина. Україна отримала 64 бали, розташувавшись у середині зони «нижче середнього». Головні проблеми в цій сфері пов'язані з недостатніми стимулюванням і нормативною підтримкою впровадження ВДЕ, а також з труднощами підключення джерел до мереж. В області доступу до енергії України має максимальні 100 балів (таку ж оцінку отримали ще багато країн).

\section{Європейські орієнтири розвитку енергетики згідно принципів сталого розвитку}

Конкретні цілі зі сталого розвитку були визначені в Європейській стратегії сталого розвитку, прийнятої країнами СС в Гетеборзі в 2001 р. У липні 2006 р. країнами $Є С$ була затверджена оновлена стратегія сталого розвитку, яка розширила тематику попередньої стратегії. У ній були виділені сім головних цілей сталого розвитку, першою з яких є зміна клімату і впровадження чистих джерел енергії (скорочення викидів парників газів, енергозбереження, зростання частки ВДЕ).

У 1992 році започатковано формування єдиної енергетичної інфраструктури Євросоюзу (Treaty on European Union, Maastrich), а у 1995 році розроблена єдина для Євросоюзу енергетична політика (White paper «An energy policy for the European Union», Brussels) [23]. У 2006 році була сформульована Європейська стратегія сталого, конкурентоспроможного і безпечного енергопостачання [11], що дозволило у 2011 році прийняти «Енергетичну дорожню карту - 2050», що передбачає декарбонізація і безпеку енергосистеми (Energy Roadmap 2050, Brussels) [15].

На саміті 23-24 жовтня 2014 р. Свропейська Рада схвалила основні напрямки політики в області клімату та енергетики до 2030 року. В основу рішення Європейської Ради покладені повідомлення Комісії від 22 січня 2014 «Основа політики в області клімату та енергетики з 2020 до 2030 року» та повідомлення Комісії від 23 липня 2014 «Енергоефективність та ї̈ внесок в енергетичну безпеку та основи політики в області клімату та енергетики до 2030 року». У висновку Свропейської ради 23-24 жовтня 2014 р. затверджені базові елементи кліматичної та енергетичної політики СС: 1) узгоджена обов'язкова на рівні ЄС мета - скоротити викиди парникових газів до 2030 року на 40 \% порівняно з рівнем 1990 року; 2) узгоджена обов'язкова на рівні ЄС мету: довести до 2030 року до $27 \%$ частку відновлюваної енергії в енергобалансі $€$; 3 ) узгоджена індикативна мета на рівні $Є С$ : до 2030 року підвищити на $27 \%$ рівень енергоефективності в порівнянні зі сценарієм «business as usual». У цьому питанні Європейська рада відійшла від пропозиції Комісії, яка наполягала на цілі в $30 \%$.

Єврокомісія 16 лютого 2016 р. представила пакет заходів щодо забезпечення енергетичної безпеки $€ \mathrm{C}$, спрямованих на підвищення безпеки і захисту європейських споживачів від можливих енергетичних криз. Пакет заходів включає: стримування попиту на енергію, зростання виробництва енергії в Свропі (в тому числі з ВДЕ); подальший розвиток добре функціонуючого та повністю інтегрованого внутрішнього енергетичного ринку; диверсифікацію енергетичних джерел, постачальників, маршрутів. Як зазначив 16 лютого 2016 р. Мігель Аріас Каньете, єврокомісар з енергетичної політики і клімату: «Сьогоднішні пропозиції спрямовані на створення надійної, конкурентоспроможної та гнучкої системи поставок енергіï».

Європейська Комісія 25 лютого 2015 р. представила стратегію побудови «Енергетичного Союзу» в Європі. Енергетичний Союз будуватиметься на наступних принципах:

1) солідарність, тобто зменшення залежності від постачальників-монополістів. ЄС введе більшу прозорість контрактів, які країни ЄС укладають для купівлі електроенергії або газу з-за меж $Є \mathrm{C}$; 
2) енергопотоки вважаються «n'ятої свободою» (поруч зі свободою пересування людей, товарів, капіталу і послуг). Це означає, що ЄС посилить вже наявні заходи щодо роз'єднання енергетичних монополій і зміцнення незалежних регуляторів. Буде перебудований європейський ринок електроенергії, щоб зробити національні ринки більш інтегрованими і з'єднаними між собою, а також з метою підвищення ролі ВДЕ;

3) енергоефективність розглядається як ще одне джерело енергії, поряд з іншими. Питання про збільшення виробництва енергії є рівноправним з питанням щодо підвищення енергоефективності;

4) перехід до низьковуглецевої економіки, тобто забезпечення того, що енергія, вироблена 3 відновлюваних джерел, буде ефективно інтегрована до енергетичних мереж. Цей пункт стратегії також передбачає перетворення ЄС в технологічного лідера у сфері зеленої енергії, у тому числі через розвиток нового покоління відновлюваної енергетики та надбання лідерської ролі у сфері виробництва електромобілів.

В рамках стратегії Європейська Комісія розглядає можливість колективної (всеєвропейської) покупки газу під час кризи, особливо в ситуаціях, де держава ЄС залежна від монопольного постачальника.

Проведений аналіз загроз глобального потепління, вичерпність викопних палив та інші чинники змушують краӥни світу суттево змінювати структуру енергетичного сектору. Краӥни Свропи розробляють і реалізують плани та стратегї̈ щзоо скорочення загального енергоспоживання за рахунок впровадження енергоефективних технологій та заміщення традиційних енергоносійв відновлюваними джерелами енерхії. Як приклад, зазначимо наступне. У 2011 році в Данії було прийнято Енергетичну стратегію до 2050 року, яка передбачає досягнення довгострокової мети - повної незалежності країни від викопних палив. Стратегія також визначає нові коротко- та середньострокові заходи для виконання національних цілей 2020 року - 33 \% ВДЕ у валовому кінцевому енергоспоживанні. Данія поставила собі за мету увійти до першої трійки країн світу з точки зору успішності впровадження ВДЕ до 2020 року та стати однією з найбільш енергоефективних країн-членів ОЕСР також до 2020 року. Розвиток енергетики в Швеції визначається Законом про інтегровану кліматичну та енергетичну стратегію (2008р.), яким встановлено низку доволі амбітних цілей. Планується досягти 50 \% ВДЕ у валовому кінцевому споживанні енергії до 2020 р., відмовитися від викопних палив в транспортному секторі до 2030 p. та досягти повної декарбонізації до 2050 року. Прийнята у 2010 р. Енергетична стратегія Німеччини до 2050 року передбачає повну відмову від використання атомної енергії до 2022 року. У 2050 році внесок ВДЕ до обсягів кінцевого енергоспоживання у Німеччині має становити $60 \%$, до споживання електроенергії - 80\%. При цьому загальне споживання первинної енергії зменшиться на 20 \% до 2020 р. та на $50 \%$ до 2050 р. від рівня 2008 р.

\section{Енергетика України на шляху сталого розвитку}

В Україні для реалізації ЦСР7 розроблена система завдань та відповідні індикатори (див. табл. 1) 3 визначенням їх чисельних значень для горизонтів планування на 2020, 2025 та 2030 роки (див. табл. 2) [7, 8]. Національна доповідь «Цілі Сталого Розвитку: Україна»є підгрунтям для подальшого стратегічного планування розвитку нашої країни [8].

Таблиця 1 - Система завдань та відповідні індикатори ЦСР7

\begin{tabular}{|c|c|}
\hline Завдання & Індикатори \\
\hline \multirow{3}{*}{$\begin{array}{l}\text { Завдання 7.1. Розширити інфраструктуру та } \\
\text { модернізувати мережі для забезпечення } \\
\text { надійного та сталого енергопостачання на } \\
\text { основі інноваційних технологій }\end{array}$} & $\begin{array}{l}\text { Індикатор 7.1.1. Виробництво електроенергії, млрд. } \\
\text { кВт·год }\end{array}$ \\
\hline & $\begin{array}{l}\text { Індикатор 7.1.2. Технологічні втрати електроенергії } \\
\text { в розподільних електромережах, \% }\end{array}$ \\
\hline & Індикатор 7.1.3. Втрати тепла в тепломережах, \% \\
\hline \multirow[t]{2}{*}{$\begin{array}{l}\text { Завдання 7.2. Забезпечити диверсифікацію } \\
\text { постачання первинних енергетичних ресурсів }\end{array}$} & $\begin{array}{l}\text { Індикатор 7.2.1. Максимальна частка імпорту } \\
\text { первинних енергоресурсів (крім ядерного палива) } 3 \\
\text { однієї країни (компанії) в загальному обсязі їх } \\
\text { постачання (імпорту), \% }\end{array}$ \\
\hline & $\begin{array}{l}\text { Індикатор 7.2.2. Частка одного постачальника на } \\
\text { ринку ядерного палива, \% }\end{array}$ \\
\hline $\begin{array}{l}\text { Завдання 7.3. Збільшити частку енергії з } \\
\text { відновлюваних джерел у національному } \\
\text { енергетичному балансі, зокрема, за рахунок } \\
\text { введення додаткових потужностей об'єктів, що } \\
\text { виробляють енергію з відновлюваних джерел. }\end{array}$ & $\begin{array}{l}\text { Індикатор 7.3.1. Частка енергії, виробленої з } \\
\text { відновлюваних джерел, у загальному кінцевому } \\
\text { споживанні енергії, \% }\end{array}$ \\
\hline $\begin{array}{l}\text { Завдання 7.4. Підвищити енергоефективність } \\
\text { економіки }\end{array}$ & $\begin{array}{l}\text { Індикатор 7.4.1. Енергоємність ВВП (витрат } \\
\text { первинної енергії на одиницю ВВП), кг н.е. на } 1 \text { дол. } \\
\text { США за ПКС } 2011\end{array}$ \\
\hline
\end{tabular}


ISSN 1813-5420 (Print). Енергетика: економіка, технологіï, екологія. 2017. № 3

Таблиця 2 - Цільові значення індикаторів ЦСР7 для України

\begin{tabular}{|c|c|c|c|c|}
\hline \multirow[t]{2}{*}{ Індикатор } & \multicolumn{4}{|c|}{ Рік } \\
\hline & $2015 \mathrm{p}$. & $2020 \mathrm{p}$. & $2025 \mathrm{p}$. & $2030 \mathrm{p}$. \\
\hline Індикатор 7.1.1 & 157,7 & 163,8 & 178,4 & 182,0 \\
\hline Індикатор 7.1.2 & 11,5 & 11,0 & 10,0 & 9,0 \\
\hline Індикатор 7.1.3 & 20 & 18 & 14 & 12 \\
\hline Індикатор 7.2.1 & 40 & $<15$ & $<12$ & $<12$ \\
\hline Індикатор 7.2.2 & $>95$ & $<70$ & $<60$ & $<50$ \\
\hline Індикатор 7.3.1 & 4,9 & 11,0 & 14,2 & 17,1 \\
\hline Індикатор 7.4.1 & 0,28 & 0,20 & 0,17 & 0,14 \\
\hline
\end{tabular}

На початку XXI ст. для координації енергетичної політики нашої держави була розроблена Енергетична стратегія України до 2030 року (затверджена розпорядженням Кабінету Міністрів України 15 березня 2006 р. № 145). У цій Стратегії визначено загальний потенціал енергозбереження за рахунок технічного (технологічного) та структурного факторів в економіці України у 2030 р. за базовим сценарієм розвитку економіки та їі секторів складатиме 318,36 млн. т у.П., у тому числі з урахуванням: галузевого технічного (технологічного) фактора - 175,93 млн. т у.п.; міжгалузевого технічного (технологічного) фактора - 22,13 млн. т у.п.; галузевого структурного фактора - 61,65 млн. т у.П.; міжгалузевого структурного фактора - 58,65 млн. т У.п. У Енергетичній стратегії до 2030 року визначено, що за рахунок реалізації потенціалу енергозбереження енергоємність ВВП у 2030 р. може скласти 0,24 кг У.П./грн. При цьому в 2010 р. енергоємність ВВП прогнозувалася на рівні 0,37 кг у.п./грн., в 2015 р. - 0,31 і в 2020 р. 0,28 кг у.п./грн. У 2030 р. порівняно з 2005 р. загальна економія паливних ресурсів за рахунок технічного фактора оцінювалася в обсязі 128,42 млн. т у.п., електричної енергії - 108,72 млрд. кВт·год, теплової енергії - 231,87 млн. Гкал, що в цілому складає 198,06 млн. т у.п.

Наступний подібний документ у липні 2013 р. розглядав уряд Азарова - це була оновлена Енергетична стратегія України до 2030 року (куратором оновлення був фонд «Ефективне управління» Рината Ахметова; цей фонд координував роботу команди із залученням Міненерговугілля та консультантів міжнародної консалтингової компанії McKinsey\&Company). У цьому оновленому варіанті Стратегії з урахуванням прогнозованого зниження витрат на будівництво об'єктів для генерації з ВДЕ та потенційних вигід для України від розвитку цієї галузі, цільовий показник сукупної потужності нетрадиційної та відновлюваної енергетики до 2030 р. має скласти щонайменше 10\% від встановленої потужності або 5-7 ГВт (10-12 ГВт включаючи великі ГЕС), а обсяг виробництва електроенергії - 11-16 ТВт·год (23-28 ТВт·год включаючи великі ГЕС). Вважалося, що ці показники можуть збільшитися за здійснення якісного стрибка в розвитку технологій будівництва об'єктів ВДЕ і, як наслідок, завдяки значному зниженню загальної собівартості генерації з ВДЕ до рівня собівартості традиційної генерації. На основі досвіду більшості європейських країн 3 впровадження ВЕС, цільовий рівень встановленої потужності вітрових електростанцій (ВЕС) в Україні до 2030 р. мав скласти 3-4 ГВт, виробництво електроенергії - 7-9 ТВт·год. Беручи до уваги досвід з впровадження сонячних електростанцій (CEС) європейських країн зі схожим рівнем сонячного випромінювання, а також 3 огляду на зниження собівартості будівництва СЕС внаслідок розвитку технологій, цільовий рівень встановленої потужності СЕС в Україні до 2030 р. зможе складати 1,5-2,5 ГВт, а рівень їх виробництво електроенергії - до 2-3,3 ТВт·год на рік за значного падіння вартості будівництва даного виду генерації. До 2030 р. потужність малих ГЕС зможе досягнути 0,4-0,8 ГВт, а обсяг виробництва електроенергії може скласти до 1,8-3,5 ТВт·год.

У 2010 році було затверджено Державну цільову економічну програму енергоефективності i розвитку сфери виробництва енергоносіїв з відновлюваних джерел енергії та альтернативних видів палива на 2010-2017 роки (постанова КМУ від 1 березня 2010 р. № 243). Ця програма визначала, зокрема, такі цілі: 1) знизити рівень енергоємності ВВП протягом строку дії Програми на 20\% порівняно з 2008 роком (щороку на 3,3\%); 2) оптимізувати структуру енергетичного балансу держави, у якому частка енергоносіїв, отриманих з відновлюваних джерел енергії та альтернативних видів палива, становитиме у 2015 році не менш як $10 \%$.

Постановою Кабінету Міністрів України від 8 листопада 2017 р. № 820 внесено зміни до постанов Кабінету Міністрів України від 1 березня 2010 р. № 243 та від 17 жовтня 2011 р. № 1056, зокрема, термін дії Державної цільової економічної програми енергоефективності і розвитку сфери виробництва енергоносіїв з відновлюваних джерел енергії та альтернативних видів палива подовжено до 2020 року включно з виділенням на енергоефективність із Державного бюджету України 2,03 млрд. грн. на період 2017-2020 роки.

У вересні 2010 року був підписаний Протокол про приєднання України до Договору про заснування 
Енергетичного співтовариства, який у подальшому ратифікований Законом України від 15 грудня 2010 р. «Про ратифікацію Протоколу про приєднання України до Договору про заснування Енергетичного Співтовариства». Згідно із зазначеним Законом з 1 лютого 2011 р. Україна стала повноправним членом Енергетичного Співтовариства.

У жовтні 2012 року ухвалено Рішення Ради Міністрів Енергетичного Співтовариства D/2012/04/MC-EnC «Про впровадження Директиви 2009/28/EC і внесення змін до Статті 20 Договору про заснування Енергетичного Співтовариства», згідно з яким кожна Сторона за Договором повинна ввести в дію закони, нормативно-правові та адміністративні положення, необхідні для виконання вимог Директиви Європейського Парламенту та Ради 2009/28/СС від 23 квітня 2009 р. про заохочення до використання енергії, виробленої з відновлюваних джерел.

Прийняття Україною Національного плану дій з енергоефективності до 2020 року є одним із основних зобов'язань в рамках імплементації Директиви 2006/32/СС щодо енергетичної ефективності кінцевого використання енергії та енергетичних послуг [10]. Кабінет Міністрів України розпорядження від 1 жовтня 2014 р. № 902-р Київ затвердив «Національний план дій з відновлюваної енергетики на період до 2020 року». Національним планом поставлено за мету досягти 11\% ВДЕ у валовому кінцевому енергоспоживанні у 2020 році, що відповідає зобов'язанням України, прийнятим перед Енергетичним Співтовариством. Національна індикативна ціль для ВДЕ у валовому кінцевому обсязі споживання енергії до 2020 року в системах опалення та охолодження, у виробництві електроенергії та транспортному секторі наведена в табл. 3 (у відсотках).

Таблиця 3 - Національні індикативні цілі для ВДЕ у валовому кінцевому обсязі споживання енергії до 2020 року

\begin{tabular}{|l|c|c|c|c|c|c|c|c|}
\hline \multicolumn{1}{|c|}{$\begin{array}{c}\text { Напрям використання енергї 3 } \\
\text { відновлюваних джерел }\end{array}$} & $\begin{array}{c}2009 \\
\text { рік }\end{array}$ & $\begin{array}{c}2014 \\
\text { рік }\end{array}$ & $\begin{array}{c}2015 \\
\text { рік }\end{array}$ & $\begin{array}{c}2016 \\
\text { рік }\end{array}$ & $\begin{array}{c}2017 \\
\text { рік }\end{array}$ & $\begin{array}{c}2018 \\
\text { рік }\end{array}$ & $\begin{array}{c}2019 \\
\text { рік }\end{array}$ & $\begin{array}{c}2020 \\
\text { рік }\end{array}$ \\
\hline $\begin{array}{l}\text { Відновлювані джерела енергії в системах } \\
\text { опалення та охолодження }\end{array}$ & 3,4 & 5,7 & 6,7 & 7,7 & 8,9 & 10,0 & 11,2 & 12,4 \\
\hline $\begin{array}{l}\text { Відновлювані джерела енергії в } \\
\text { електроенергетиці }\end{array}$ & 7,1 & 7,6 & 8,3 & 8,8 & 9,7 & 10,4 & 10,9 & 11 \\
\hline $\begin{array}{l}\text { Відновлювані джерела енергії у } \\
\text { транспортному секторі }\end{array}$ & 1,5 & 4,1 & 5 & 6,5 & 7,5 & 8,2 & 9 & 10 \\
\hline $\begin{array}{l}\text { Загальна частка відновлюваних джерел } \\
\text { енергії }\end{array}$ & 3,8 & 5,9 & 6,7 & 7,4 & 8,3 & 9,1 & 10,1 & 11 \\
\hline
\end{tabular}

У листопаді 2015 року в Україні було прийнято Національний план дій з енергоефективності на період до 2020 року (розпорядження КМУ № 1228-р від 25.11.2015). Планом передбачено досягнення у 2020 році національної індикативної мети з енергозбереження в обсязі 9 \% від середнього показника кінцевого енергоспоживання за період 2005-2009 pp., що еквівалентне 6,5 млн. т н.е. 3 його прийняттям Україна отримала можливість запровадити європейську практику планування та прогнозування розвитку енергетики, реалізації політики підвищення енергоефективності. Згідно з Планом, передбачено досягнення у 2020 році національної індикативної мети щодо енергозбереження у розмірі $9 \%$ від середнього показника кінцевого внутрішнього енергоспоживання за період протягом 2005-2009 рр., що становить 6,5 млн. т н.е. Крім того, Національний план дій визначає проміжну мету - у 2017 році скоротити енергоспоживання в розмірі 5 \%. Основні завдання:

- досягнути обсягів збереженої енергії у 2020 р. у розмірі 9 \% від середніх обсягів кінцевого споживання, а саме 6283 тис. т н.е.;

- знизити енергоємність виробництва одиниці продукції, виконання робіт, надання послуг на 9 \% від рівня 2012 р.;

- скоротити рівень витрат теплової енергії в громадських житлових будівлях на 50 \% від рівня 2012

p.;

- скоротити середнє питоме річне енергоспоживання житлового фонду України та привести його до норм та стандартів СС;

- зменшити на 15-20 \% обсяги використання природних ресурсів за рахунок зменшення обсягів їх споживання;

- забезпечити зменшення на 15-20 \% обсягів викидів забруднюючих речовин;

- підвищити рівень надання комунальних послуг для всіх верств населення.

Очікувана економія від реалізації Національного плану дій з енергоефективності на період до 2020 року: у 2017 р. - 3613 тис. т н.е.; у 2020 р. - 6501 тис. т н.е. Загальне фінансування на період 2015-2020 pр. - 35070 млн. євро.

Досягти наведених показників планується шляхом реалізації заходів у чотирьох основних секторах 


\section{ISSN 1813-5420 (Print). Енергетика: економіка, технології, екологія. 2017. № 3}

кінцевого споживання енергії: побутовий сектор (очікується найбільший ефект), сектор послуг (також входить енергоспоживання бюджетних установ), у промисловості та на транспорті. Серед основних заходів: сприяння залученню інвестицій в термомодернізацію житлових будівель та у будівництво споруд 3 близьким до нульового споживанням енергії; адаптація стандартів палива та технологій його використання до європейських; запровадження сертифікації енергетичної ефективності будівель, системи енергоаудиту та енергоменеджменту; встановлення мінімальних вимог до енергоефективності будівель та енергоспоживчих продуктів (обладнання), забезпечення функціонування системи енергетичного маркування електрообладнання побутового призначення; забезпечення 100 \% комерційного обліку споживання газу, теплової енергії та води і впровадження рахунків про оплату спожитої енергії 3 інформаційно-аналітичними даними щодо динаміки обсягів споживання енергії та комунальних послуг тощо.

Розпорядженням Кабінету Міністрів України від 18 серпня 2017 р. № 605-р. схвалена Енергетична стратегія України на період до 2035 року «Безпека, енергоефективність, конкурентоспроможність». Ключові показники ефективності Енергетичної стратегії України на період до 2035 року наведено в табл. 4.

Таблиця 4 - Ключові показники ефективності Енергетичної стратегії України на період до 2035 року

\begin{tabular}{|c|c|c|c|c|c|}
\hline Опис ключового показника ефективності & $\begin{array}{l}2015 \\
\text { рік }\end{array}$ & $\begin{array}{l}2020 \\
\text { рік }\end{array}$ & $\begin{array}{l}2025 \\
\text { рік }\end{array}$ & $\begin{array}{l}2030 \\
\text { рік }\end{array}$ & $\begin{array}{l}2035 \\
\text { рік }\end{array}$ \\
\hline \multicolumn{6}{|c|}{ Підвищення енергоефективності } \\
\hline $\begin{array}{l}\text { Енергоємність ВВП, ЗППЕ* у т н.е./тис. дол. ВВП } \\
\text { (ПКС) }\end{array}$ & 0,28 & 0,20 & 0,18 & 0,15 & 0,13 \\
\hline $\begin{array}{l}\text { Витрати палива на обсяг спрямованої на енергоринок } \\
\text { електроенергії, виробленої на ТЕС, г у.п./кВт·год }\end{array}$ & 396 & 384 & 367 & 353 & 334 \\
\hline $\begin{array}{l}\text { Питомі витрати при виробництві тепла котельнями, } \\
\text { кг у.п./Гкал }\end{array}$ & 165 & 160 & 155 & 150 & 145 \\
\hline Частка втрат в електромережах, \% & $>12 \%$ & $10 \%$ & $9 \%$ & $8 \%$ & $<7,5 \%$ \\
\hline Частка втрат у тепломережах, \% & $>20 \%$ & $<17 \%$ & $<13 \%$ & $<11 \%$ & $<10 \%$ \\
\hline \multicolumn{6}{|c|}{ Безпека і екологія } \\
\hline $\begin{array}{l}\text { Частка ВДЕ (включно з гідрогенеруючими } \\
\text { потужностями та термальною енергією) у ЗППЕ, \% }\end{array}$ & $4 \%$ & $8 \%$ & $12 \%$ & $17 \%$ & $25 \%$ \\
\hline $\begin{array}{l}\text { Частка ВДЕ (включно з гідрогенеруючими } \\
\text { потужностями) у генерації електроенергії, \% }\end{array}$ & $5 \%$ & $7 \%$ & $10 \%$ & $>13 \%$ & $>25 \%$ \\
\hline $\begin{array}{l}\text { Частка місцевих альтернативних видів палива в } \\
\text { місцевих паливно-енергетичних балансах, \% до } \\
\text { загального споживання }\end{array}$ & & 10 & 15 & 18 & 20 \\
\hline Викиди $\mathrm{CO}_{2}$ до рівня 1990 року & - & $<60 \%$ & $<60 \%$ & $<60 \%$ & $<50 \%$ \\
\hline $\begin{array}{l}\text { Зниження викидів в } \mathrm{CO}_{2} \text { екв. На кінцеве споживання } \\
\text { палива, \% від } 2010 \text { року }\end{array}$ & & $>5$ & $>10$ & $>15$ & $>20$ \\
\hline $\begin{array}{l}\text { Частка потужностей у тепловій генерації, що відповідає } \\
\text { екологічним вимогам } \mathrm{CC} \mathrm{(викиди} \mathrm{SO}_{2}, \mathrm{NO}_{x}, \text { золи), \% }\end{array}$ & $<1 \%$ & $<10 \%$ & $<40 \%$ & $85 \%$ & $100 \%$ \\
\hline
\end{tabular}

* - ЗППЕ - загальне постачання первинної енергії

Фахівцями КПІ імені Ігоря Сікорського розроблено форсайт економіки України [42]. Головні кластери майбутньої економіки України та пріоритетність їх внеску в загальне зростання (у відсотках, у періодах 2015-2020 та 2020-2030рр.) [42]: аграрний сектор (14 та 17); військово-промисловий комплекс (13 та 15); інформаційно-телекомунікаційні технології (8 та 12); створення нових речовин і матеріалів, нанотехнології (7 та 12); енергетика (7 та 11); високотехнологічне машинобудування (8 та 8); розвиток транзитної інфраструктури (2 та 5); «науки про життя» (біомедична інженерія, клітинна медицина, фармація) (1 та 5); туризм (2 та 5); інші кластери (переважно низькотехнологічні та сировинні) (40 та 10).

Показники енергетичної трилеми Світової енергетичної ради

Світова Енергетична Рада (World Energy Council, WEC) для реалізації проектів сталої енергетики розробила «Концепцію енергетичної трилеми», яка стала відповіддю на сучасну потрійну енергетичну задачу, яка полягає в підтримці безпечної, доступної та екологічно чистої енергії. Баланс оцінюється за допомогою індексу, розробленого СЕР (World Energy Trilemma Index) [19, 20, 22]. 
ISSN 1813-5420 (Print). Енергетика: економіка, технології, екологія. 2017. № 3

Індекс, випущений до конференції СОР-18 в Досі (Катар) у грудні 2012 року, є складовою частиною доповіді СЕР 2012 року з проблеми світової енергетичної трилеми (World Energy Trilemma report) під назвою «Час бути реалістами - аргументація на користь політики стійкої енергетики» («Time to get real the case for sustainable energy policy»), який оцінює країни з урахуванням їх клімату і енергетичних показників [20]. 3 доповіді випливає, що більшість країн до сих пір не зуміли знайти збалансований підхід до вирішення трьох суперечливих нагальних проблем, які СЕР називає «енергетичною трилемою».

Розроблена СЕР «Концепція енергетичної трилеми» фокусується на трьох основних векторах розвитку ПЕК: енергобезпека, доступність енергії та екологічна стійкість. Досягнення балансу між цими складовими неможливо без міжнародної співпраці на різних рівнях та інтеграції енергосистем. Кожній державі, згідно $з$ концепцією, необхідно дотримуватися балансу між трьома «стовпами» трилеми. Так, країни, що визначають екологію як найвищий пріоритет (за рахунок використання геотермальної та гідроенергетики), такі як Ісландія, Колумбія і Філіппіни, можуть виявитися занадто залежними від одного джерела енергії, що знижує рівень енергобезпеки. Нафтовидобувним державам, навпаки, слід розширювати використання відновлюваних джерел енергії. Енергетична трилема включає [19]:

Таблиця 5 - Складові для методики розрахунку індексу енергетичної стійкості СЕР

\begin{tabular}{|c|c|}
\hline Сфера, внесок у відсотках & Показник (з визначенням частки внеску) \\
\hline \multirow[t]{6}{*}{ Енергетична безпека - 25\% } & $\begin{array}{l}\text { 1.1.1 Відношення виробництва первинних енергоресурсів до споживання } \\
-\mathbf{1 / 5}\end{array}$ \\
\hline & 1.1.2 Різноманітність джерел генерації електроенергії - 1/5 \\
\hline & 1.1.3 Оптова надбавка на моторні палива $-\mathbf{1 / 5}$ \\
\hline & 1.1.4 П'ятирічне зростання споживання первинних енергоресурсів - 1/5 \\
\hline & 1.1.5а Для експортерів - різноманітність джерел експорту енергії - 1/5 \\
\hline & 1.1.5b Для імпортерів - норма стратегічного запасу нафти - 1/5 \\
\hline \multirow[t]{2}{*}{ Соціальна рівність - $\mathbf{2 5 \%}$} & 1.2.1 Доступність моторних палив в роздрібному продажу - 1/2 \\
\hline & 1.2.2 Доступність і якість електроенергії з урахуванням доступу $-\mathbf{1 / 2}$ \\
\hline \multirow{4}{*}{$\begin{array}{l}\text { Мінімізація } \text { впливу на } \\
\text { навколишнє середовище - } \\
\mathbf{2 5 \%}\end{array}$} & 1.3.1 Енергоємність ВВП на душу населення - $\mathbf{1 / 4}$ \\
\hline & 1.3.2 Кількість викидів на ВВП на душу населення - 1/4 \\
\hline & 1.3.3 Викиди $\mathrm{CO}_{2}$ від виробництва електроенергії і тепла $-\mathbf{1 / 4}$ \\
\hline & 1.3.4 Вплив забруднення повітря і води - 1/4 \\
\hline \multirow{3}{*}{$\begin{array}{l}\text { Політичне середовище - } \\
\mathbf{8 , 3 \%}\end{array}$} & 2.1.1 Політична стабільність $-\mathbf{1 / 3}$ \\
\hline & 2.1.2 Якість нормативно-правового регулювання - 1/3 \\
\hline & 2.1.3 Ефективність уряду $-\mathbf{1 / 3}$ \\
\hline \multirow{4}{*}{$\begin{array}{l}\text { Соціальне середовище - } \\
\mathbf{8 , 3 \%}\end{array}$} & 2.2.1 Контроль корупції - 1/4 \\
\hline & 2.2.2 Верховенство закону $-\mathbf{1 / 4}$ \\
\hline & 2.2 .3 Якість освіти $-\mathbf{1 / 4}$ \\
\hline & 2.2.4 Якість охорони здоров'я - $\mathbf{1 / 4}$ \\
\hline \multirow{3}{*}{$\begin{array}{l}\text { Економічне середовище - } \\
\mathbf{8 , 3 \%}\end{array}$} & 2.3.1 Вартість життя $-\mathbf{1 / 3}$ \\
\hline & 2.3.2 Макроекономічна стабільність $-\mathbf{1 / 3}$ \\
\hline & 2.3.3 Доступність кредиту для приватного сектора $-\mathbf{1 / 3}$ \\
\hline
\end{tabular}

1) енергетичну безпеку - ефективну організацію поставки первинної енергії з національних і зарубіжних джерел, надійність енергетичної інфраструктури та здатність постачальників енергії задовольнити поточний і майбутній попит;

2) енергетична рівність - наявність і доступність енергії для населення;

3) екологічну стійкість - визначає ефективність пропозиції та попиту енергії, а також розвиток пропозиції енергії з ВДЕ і інших низьковуглецевих джерел [5].

Індекс енергетичної стійкості являє собою комплексну оцінку енергетичного сектора держави в аспекті сталого розвитку в світовому масштабі.

Запропоновано 10 кроків до змін енергетики згідно «Концепції енергетичної трилеми» WEC:

1) забезпечити зв'язок енергетичної трилеми з більш масштабною державною програмою;

2) здійснювати керівництво, спрямоване на досягнення консенсусу в національному і міжнародному масштабі;

3) налагодити більш ефективний діалог між представниками промисловості та вищої державної влади;

4) мінімізувати політичні та законодавчі ризики і досягти оптимального розподілу ризиків;

5) ринковий підхід до тарифікації викидів вуглекислого газу з метою підвищення інвестиційної привабливості; 
6) розробити прозорі, гнучкі і динамічні системи тарифікації;

7) сприяти лібералізації (екологічної) господарської діяльності;

8) активніше взаємодіяти з фінансовими установами;

9) задовольняти потребу в більш активних дослідженнях, розробках і демонстрації;

10) підтримувати спільні пілотні галузеві ініціативи, включаючи великомасштабну річну демонстрацію і розгортання.

Останні Доповіді СЕР говорить про те, що енергосистеми все ще далекі від сталого свого розвитку [19, 20, 22]. У звіті «World Energy Trilemma: Time to get real - the agenda for change» СЕР представляє ранги країн відповідно до індексу енергетичної сталості (Energy Sustainability Index) [20]. Індекс енергетичної сталості показує, що більшість з більш ніж 90 розглянутих країн все ще далекі від того, щоб забезпечити повну стійкість своїх енергосистем. Сьогодні дев'ять 3 десяти країн-лідерів у рейтингу індексу європейські (на 9 місці Нова Зеландія, Україна займає 63 позицію з 125). У табл. 5 представлені складові для методики розрахунку індексу енергетичної стійкості СЕР.

Україна у 2016 році, посівши 63 місце в загальному рейтингу країн за Energy Trilemma Index, покращила свої позиції у загальному рейтингу на 2 позиції з 2015 р. [18]. У питаннях енергетичної безпеки та рівності Україна досягла значних успіхів, маючи рейтингові оцінки А (28) та В (61) відповідно. Слабким місцем нашої країни $є$ екологічна стійкість, даний показник відповідає рейтинговій оцінці D (108). Однак на сьогодні український енергетичний сектор зіткнувся 3 досить великими проблемами, що й демонструють наведені показники. У табл. 6 представлено порівняння складових енергетичної трилеми України та окремих країн Європи.

Таблиця 6 - Порівняння країн за показниками енергетичної трилеми

\begin{tabular}{|c|c|c|c|c|}
\hline Країна & Номер в рейтингу & $\begin{array}{c}\text { Індекс } \\
\text { енергетичної } \\
\text { безпеки }\end{array}$ & $\begin{array}{c}\text { Індекс } \\
\text { енергетичної } \\
\text { рівності }\end{array}$ & $\begin{array}{c}\text { Індекс екологічної } \\
\text { стійкості }\end{array}$ \\
\hline Україна & 63 & $\mathrm{~A}(28)$ & $\mathrm{B}(61)$ & $\mathrm{D}(108)$ \\
\hline Польща & 36 & $\mathrm{~B}(60)$ & $\mathrm{A}(28)$ & $\mathrm{B}(64)$ \\
\hline Росія & 45 & $\mathrm{~A}(6)$ & $\mathrm{B}(42)$ & $\mathrm{D}(116)$ \\
\hline Німеччина & 5 & $\mathrm{~A}(7)$ & $\mathrm{A}(15)$ & $\mathrm{A}(31)$ \\
\hline Швеція & 3 & $\mathrm{~A}(10)$ & $\mathrm{A}(27)$ & $\mathrm{A}(8)$ \\
\hline Словаччина & 16 & $\mathrm{~A}(15)$ & $\mathrm{A}(18)$ & $\mathrm{A}(30)$ \\
\hline США & 14 & $\mathrm{~A}(4)$ & $\mathrm{A}(13)$ & $\mathrm{C}(73)$ \\
\hline Данія & 1 & $\mathrm{~A}(1)$ & $\mathrm{A}(10)$ & $\mathrm{A}(6)$ \\
\hline
\end{tabular}

Дані, наведені у табл. 7, відображають відмінності у структурі енергетичного балансу України та окремих країн, розвиток яких для нас $є$ орієнтиром. Можна помітити, що для країн, які займають передові місця у світовому рейтингу, є властивим широке використання ВДЕ.

Щодо використання ВДЕ в нашій країні зауважимо наступне. За даними Мінпаливенерго установлена потужність ВЕС та СЕС на початок 2017 р. складала відповідно 438 та 531 МВт, що становило 1,6 \% питомої ваги потужностей українських електростанцій (без урахування об'єктів відновлюваної електроенергетики, що знаходяться на тимчасово окупованій території АР Крим). Виробництво електроенергії у 2016 р. ВЕС та СЕС становила відповідно 925 та 492 млн. кВт·год, тобто сумарно 0,9 \% від загального виробництва електроенергії (147777 млн. кВт·год). За період 2014-2016 рр. установлена потужність ВЕС зросла на 6,6 \% та СЕС - на $29 \%$, тоді як річне виробництво електроенергії для ВЕС знизилося на $18,1 \%$, а для СЕС - зросло на $14,7 \%$.

Таблиця 7 - Порівняння енергетичного балансу країн за виробництвом та постачанням енергії

\begin{tabular}{|l|l|l|l|l|l|}
\hline & Україна & Німеччина & Польща & Данія & США \\
\hline \multicolumn{2}{|c|}{ Різноманітність загального обсягу постачання первинної енергії, \% } & \multicolumn{4}{l|}{} \\
\hline -вугілля & 35,82 & 25,48 & 54,12 & 18,11 & 19,79 \\
\hline -природній газ & 34,04 & 22,81 & 14,01 & 19,11 & 27,93 \\
\hline
\end{tabular}


ISSN 1813-5420 (Print). Енергетика: економіка, технологіï, екологія. 2017. № 3

Продовження таблиці 7

\begin{tabular}{|l|l|l|l|l|l|}
\hline -нафта & 8,55 & 32,11 & 22,68 & 35,23 & 35,74 \\
\hline -ВДЕ/атомна & $1,71 / 18,85$ & $11,07 / 7,91$ & 8,98 & 27,55 & $5,66 / 9,81$ \\
\hline -гідро & 1,02 & 0,62 & 0,21 & - & 1,07 \\
\hline Різноманітність виробництва електроенергії, \% & \multicolumn{5}{l|}{} \\
\hline -традиційна теплова & 48,72 & 59,79 & 89,10 & 49,28 & 68,56 \\
\hline -гідроенергетика & 5,52 & 3,33 & 1,18 & 0,06 & 6,7 \\
\hline -ядерна енергетика & 45,36 & 16,08 & - & - & 19,01 \\
\hline -ВДЕ & 0,4 & 20,8 & 9,72 & 50,68 & 5,73 \\
\hline
\end{tabular}

Аналіз розвитоку енергетики України на базі даних Enerdata Yearbook

Для детального співставлення показників України та окремих країн використаємо інформацію бази даних Enerdata Yearbook [14]. За даними Всесвітнього банку даних Enerdata Yearbook є можливість відслідковувати для окремих країн та регіонів в цілому динаміку таких показників як енергоємність, споживання та виробництво енергії тощо. Для подальшого аналізу виберемо групу країн у складі Україна, Німеччина, Польща та Росія. Наведемо окремі показники, які досить повно характеризують роль та місце України у світовому енергобалансі.

3 даних, наведених на графіках рис. 1 та 2, випливає, що в питанні енергоємності Україна слідує світовим тенденціям щодо зменшення інтенсивності використання енергії. Але, на жаль, рівень енергоємності в Україні залишається одним із найвищих в світі - 0,318 kep/\$2005p. за даними Enerdata та $\epsilon$ другим за величиною після Росії. У табл. 8 показано першу та останню п’ятірку країн щодо їх рівнів енергоємності (згідно переліку країн, що входять до бази даних Enerdata Yearbook (енергоємність економіки України перевищує середньосвітовий показник в 2,21 рази.

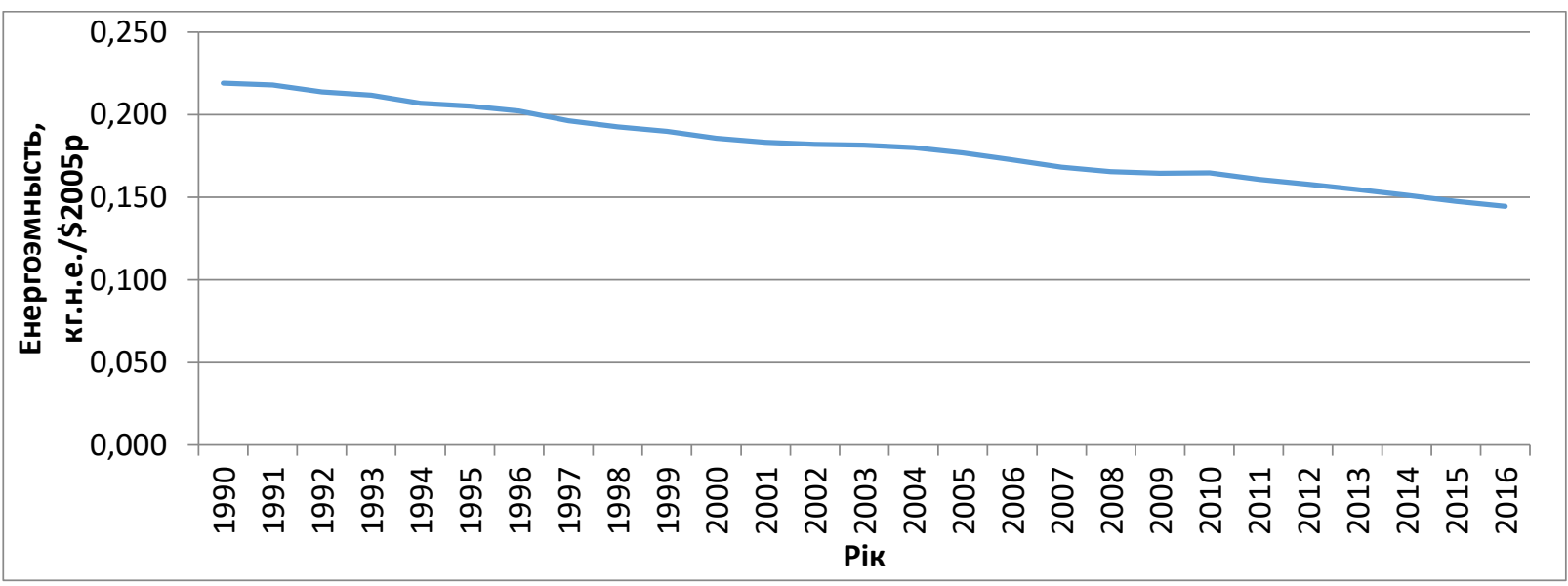

Рисунок 1 - Динаміка світової енергоємності.

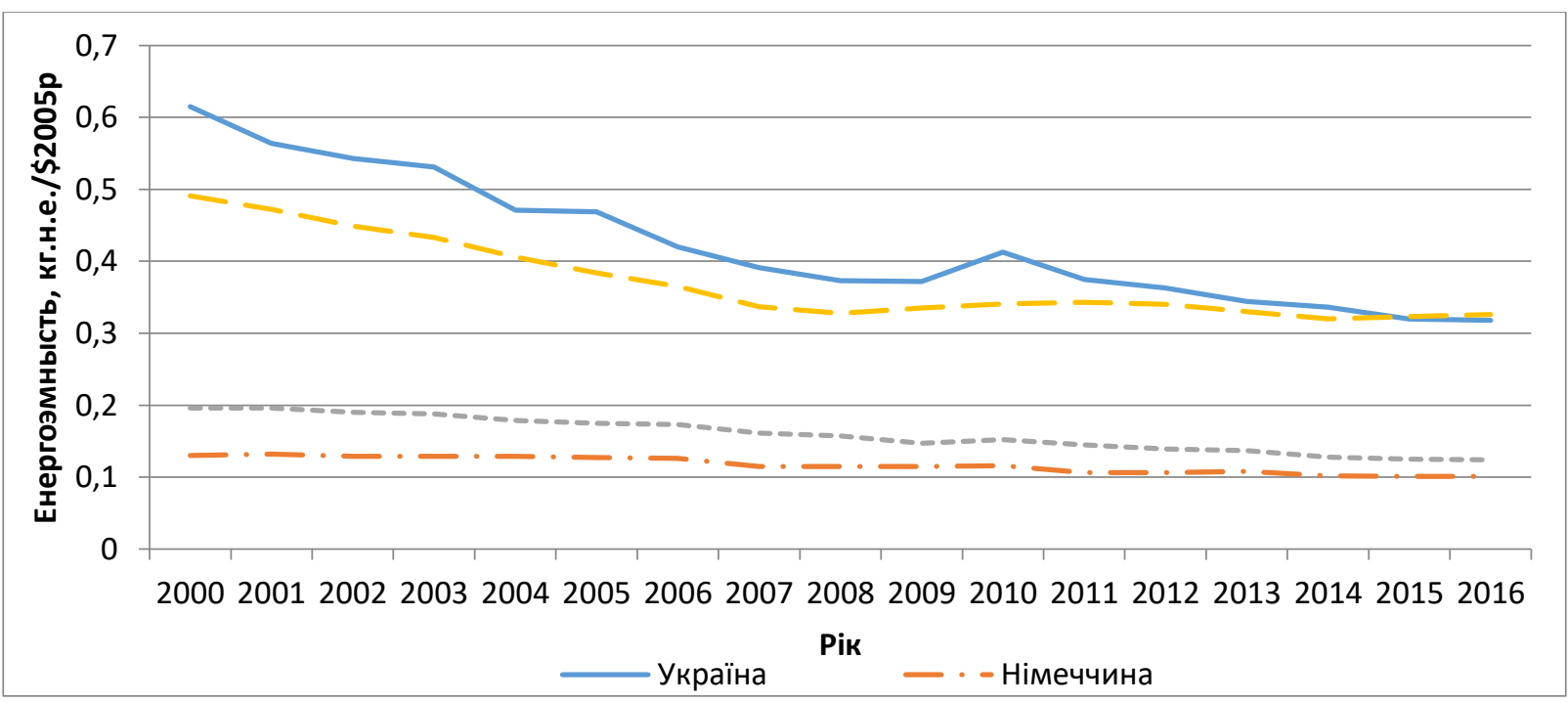

Рисунок 2 - Порівняння зміни енергоємності України відносно Німеччини, Польщі та Росії 
Таблиця 8 - Рейтинг країн за рівнем енергоємності

\begin{tabular}{|l|l|l|l|}
\hline \multicolumn{2}{|l|}{ Енергоємність, кг.н.е./\$2005p. } \\
\hline Перша п’ятірка & 0,326 & Остання п’ятірка \\
\hline Росія & 0,318 & Іспанія & 0,093 \\
\hline Україна & 0,262 & Сгипет & 0,092 \\
\hline Узбекистан & 0,239 & Індонезія & 0,087 \\
\hline ПАР & 0,22 & Великобританія & 0,074 \\
\hline Тайвань & 0,144 & Колумбія & 0,057 \\
\hline Світ & Україна & 0,318 \\
\hline
\end{tabular}

На рис. 3-7 для України, Німеччини, Польщі та Росії наведено наступні характеристики: рис. 3 динаміка виробництва сумарної енергії в млн. т н.е.; рис. 4 - частка ВДЕ (\%) у виробництві енергії; рис. 5 - динаміка споживання сумарної енергії в млн. т.н.е; рис. 6 - динаміка виробництва електроенергії в ТВт·год; рис. 7 - внутрішне споживання електроенергії вТВт·год. Рейтинг країн світу за рівнем виробництва та споживання енергії нведено в табл. 9.

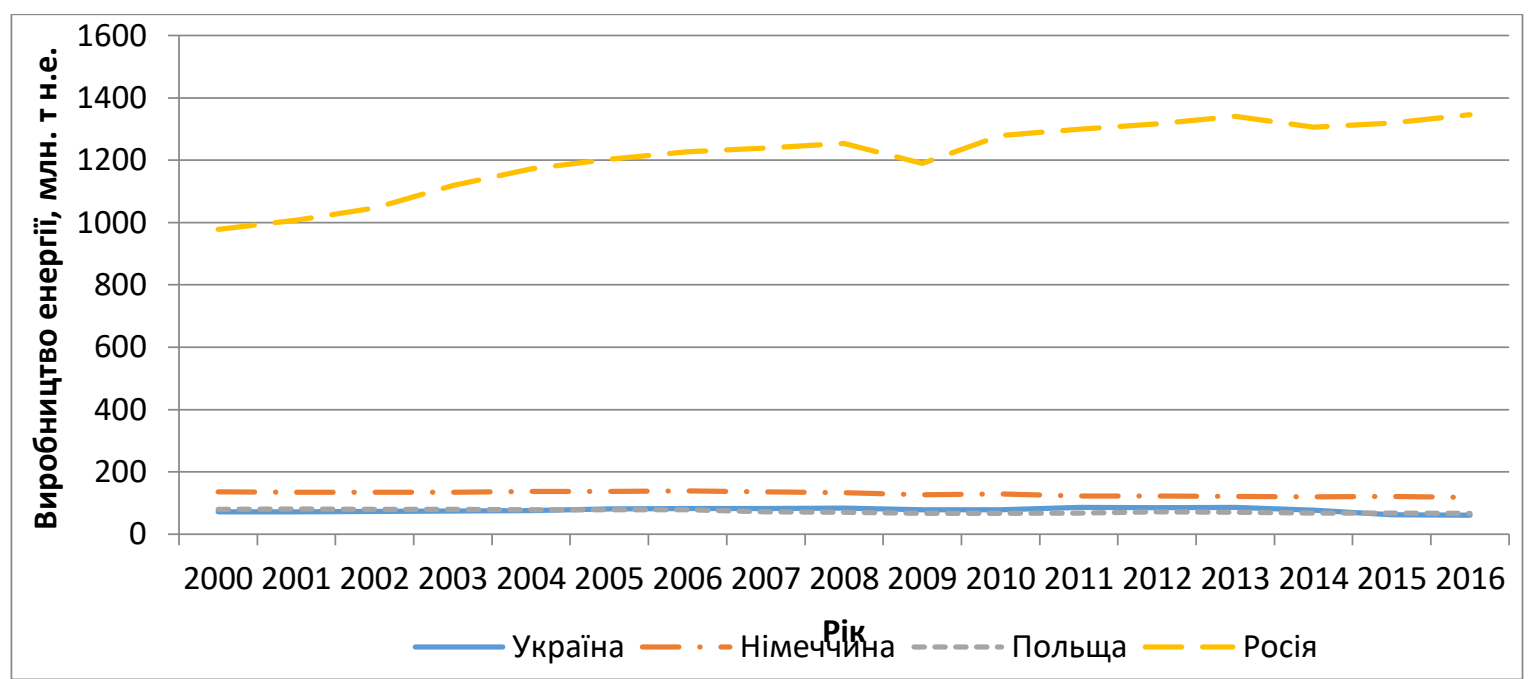

Рисунок 3 - Динаміка виробництва сумарної енергії (млн. т н.е.) в Україні порівняно 3 Німеччиною, Польщею та Росією

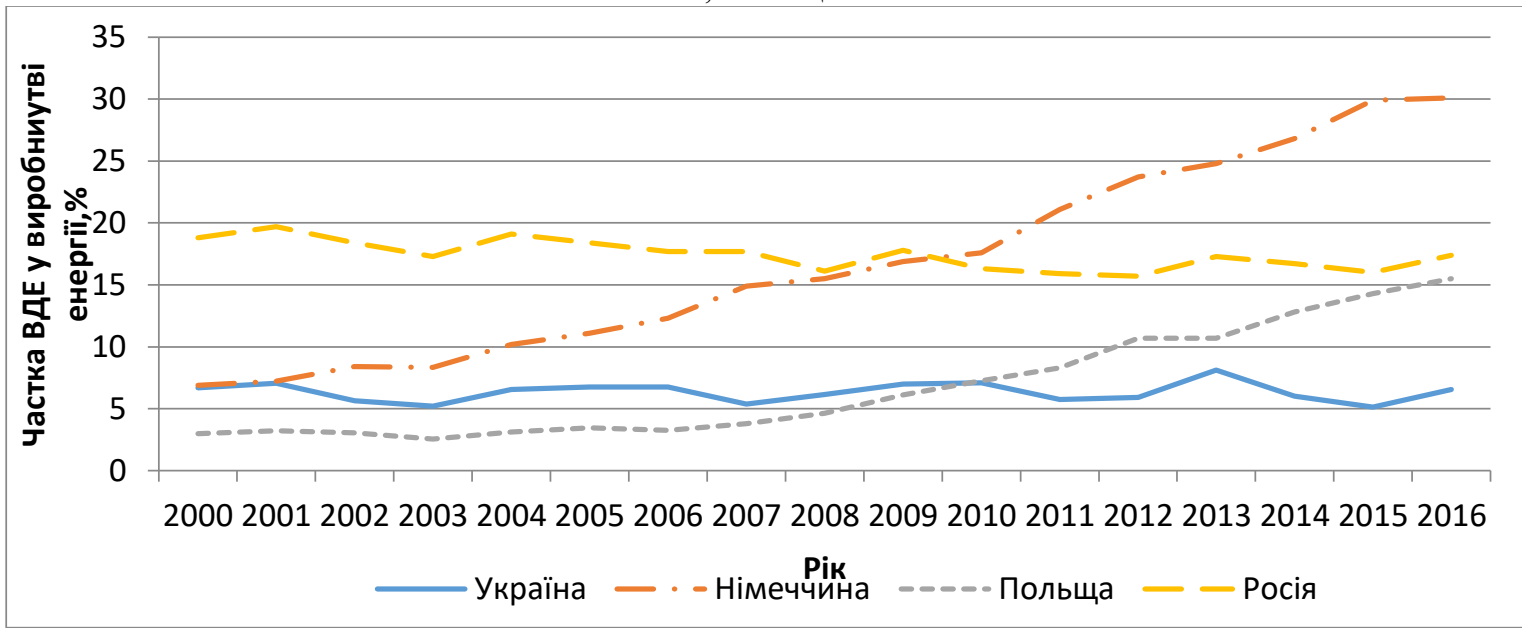

Рисунок 4 - Частка ВДЕ у виробництві енергії в Україні порівняно з Німеччиною, Польщею та Росією 
ISSN 1813-5420 (Print). Енергетика: економіка, технології, екологія. 2017. № 3

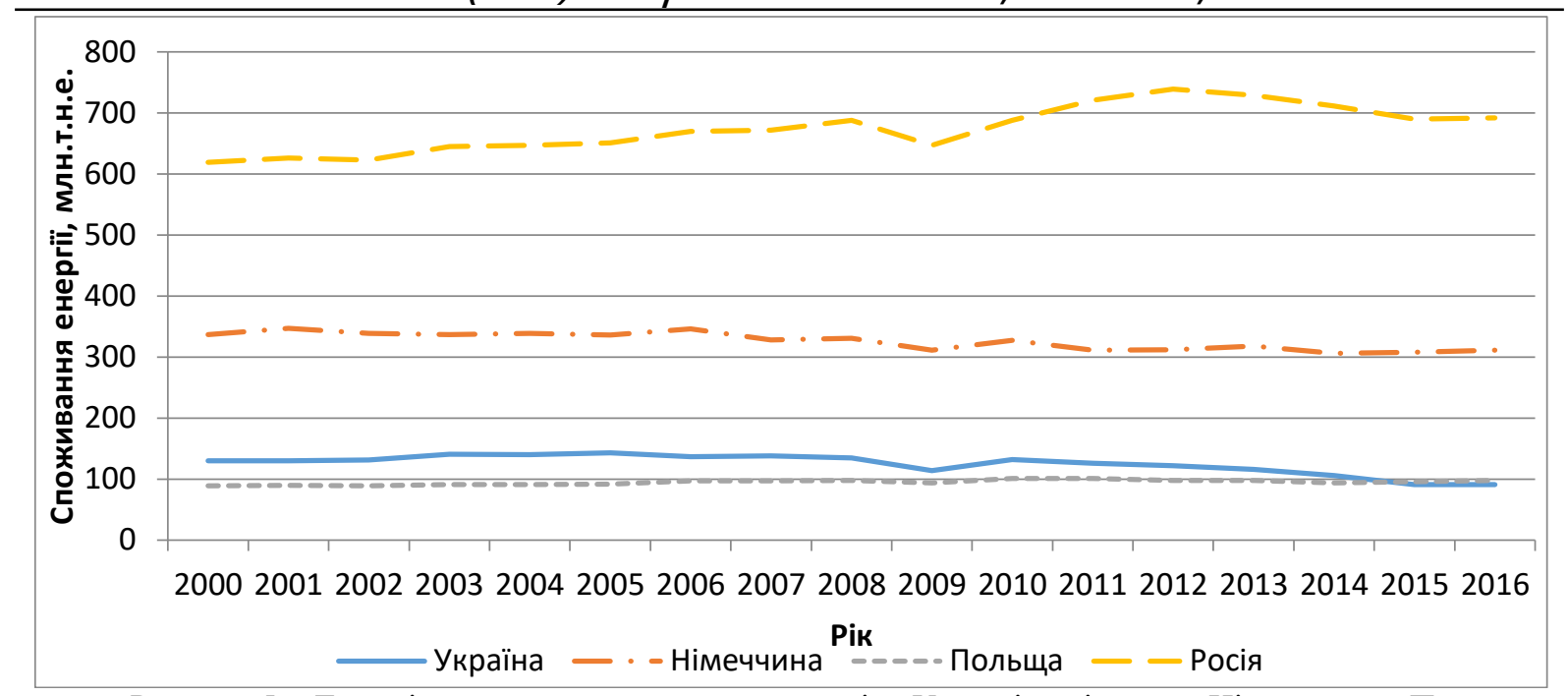

Рисунок 5 - Динаміка споживання сумарної енергії в Україні порівняно з Німеччиною, Польщею та Росією

Таблиця 9 - Рейтинг країн світу за рівнем виробництва та споживання енергії

\begin{tabular}{|l|l|l|l|}
\hline \multicolumn{4}{|l|}{ Загальне виробництво енергії, млн. т н.е. } \\
\hline Перша п’ятірка & \multicolumn{3}{l|}{ Остання п’ятірка } \\
\hline Китай & 2538 & Нова Зеландія & 16 \\
\hline США & 1952 & Бельгія & 15 \\
\hline Росія & 1346 & Чилі & 12 \\
\hline Саудівська Аравія & 685 & Тайвань & 11 \\
\hline Індія & 586 & Португалія & 6 \\
\hline Світ & 13910 & Україна & 61 \\
\hline Загальне споживання енергії, млн. т н.е. & \multicolumn{2}{l|}{} \\
\hline Перша п’ятірка & \multicolumn{5}{|l|}{} \\
\hline Китай & 3123 & Остання п’ятірка & 33 \\
\hline США & 2204 & Колумбія & 33 \\
\hline Індія & 884 & Румунія & 30 \\
\hline Росія & 682 & Норвегія & 22 \\
\hline Японія & 437 & Португалія & 21 \\
\hline Світ & 13903 & Нова Зеландія & 91 \\
\hline
\end{tabular}

Рівень споживання та виробництва електроенергії в Україні виглядає наступним чином: 
ISSN 1813-5420 (Print). Енергетика: економіка, технології, екологія. 2017. № 3

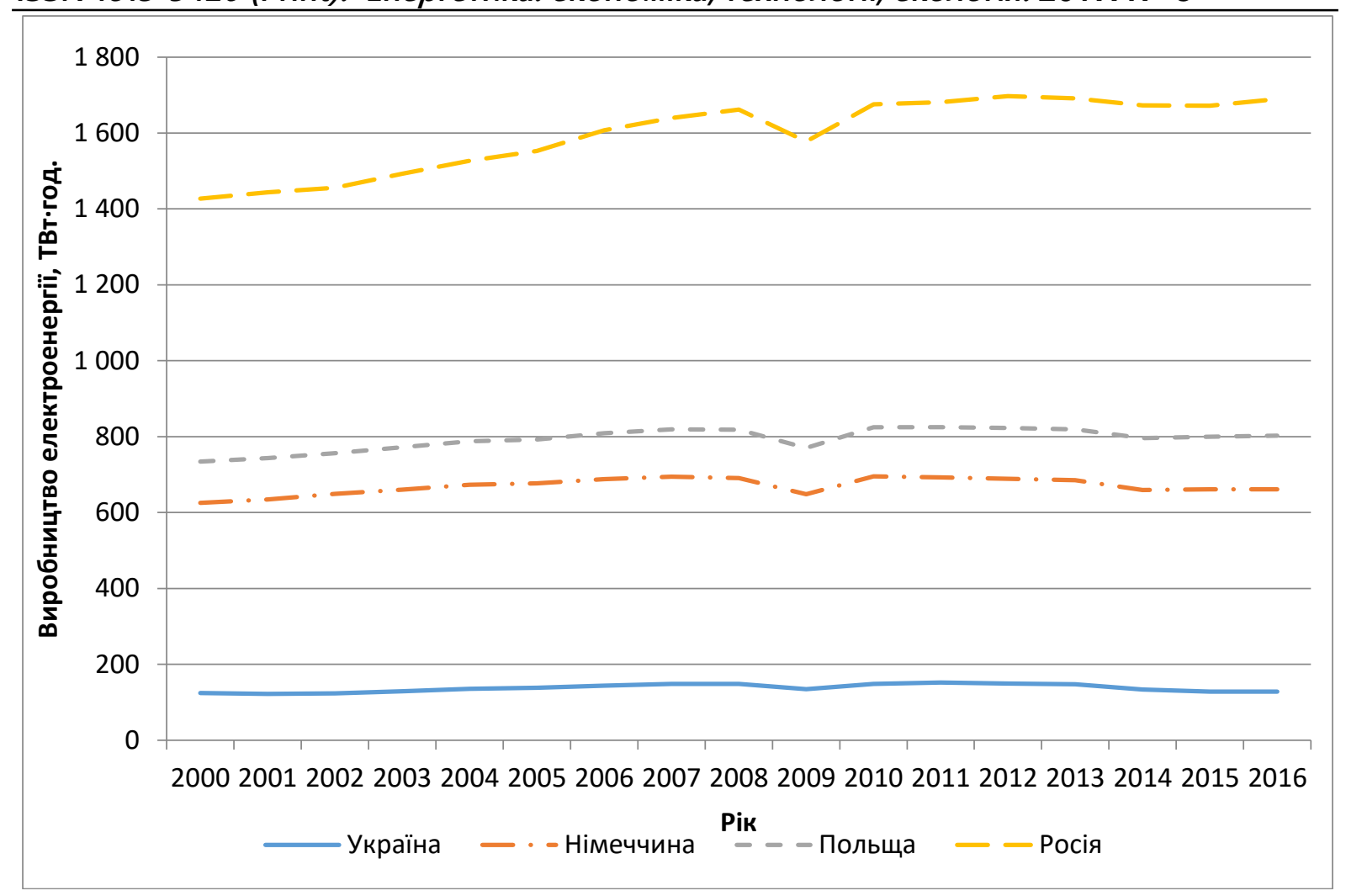

Рисунок 6 - Динаміка виробництва електроенергії в Україні порівняно з Німеччиною, Польщею та Росією

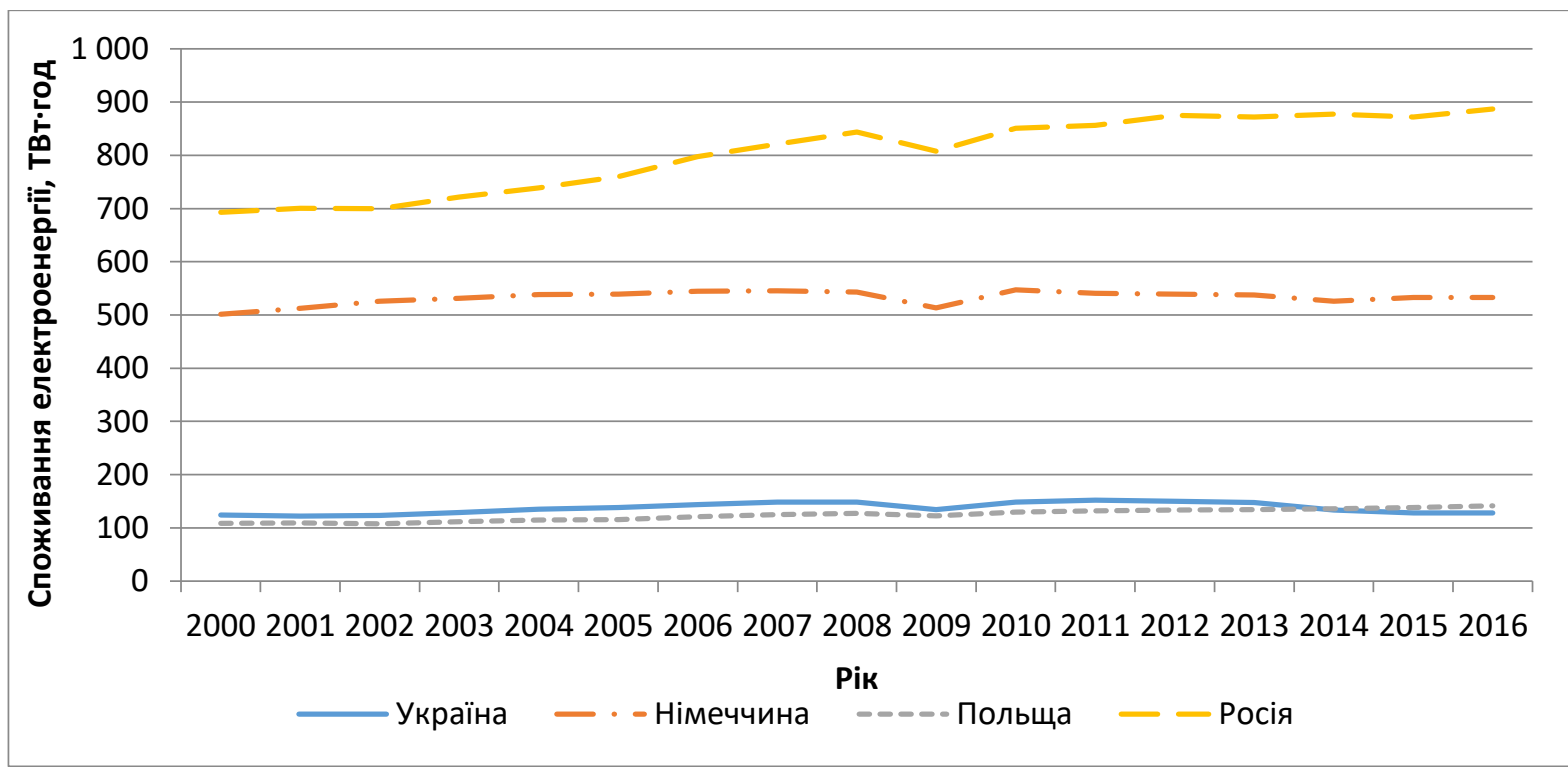

Рисунок 7 - Внутрішнє споживання електроенергії в Україні порівняно з Німеччиною, Польщею та Росією

Як випливає із графіків на рис. 6 та 7, рівень виробництва електроенергії перевищує рівень споживання. Це пояснюється не тільки тим, що Україна є країною експортером електроенергії ( у 2015 році Україна експортувала 3,75 млн. кВт·год електричної енергії в сусідні країни), але й суттєвими втратами на передачу та розподіл електричної енергії, в Україні цей показник за даними СЕР складає $12,3 \%$.

Рейтинг країн світу за рівнем споживання та виробництва електроенергії представлено в табл. 10 , що не відповідає потенційним можливостям нашої держави. 
ISSN 1813-5420 (Print). Енергетика: економіка, технології, екологія. 2017. № 3

Таблиця 10 - Рейтинг країн світу за рівнем споживання та виробництва електроенергії

\begin{tabular}{|c|c|c|c|}
\hline \multicolumn{4}{|c|}{ Виробництво електроенергії, ТВт·год } \\
\hline \multicolumn{2}{|c|}{ Перша п’ятірка } & \multicolumn{2}{|c|}{ Остання п’ятірка } \\
\hline Китай & 6015 & Румунія & 68 \\
\hline США & 4327 & Португалія & 61 \\
\hline Індія & 1423 & Узбекистан & 59 \\
\hline Росія & 1088 & Нова Зеландія & 44 \\
\hline Японія & 1013 & Нігерія & 30 \\
\hline Світ & 24660 & Україна & 164 \\
\hline \multicolumn{4}{|c|}{ Споживання електроенергії, ТВт·год } \\
\hline \multicolumn{2}{|c|}{ Перша п’ятірка } & \multicolumn{2}{|c|}{ Остання п’ятірка } \\
\hline Китай & 5129 & Румунія & 51 \\
\hline США & 3867 & Узбекистан & 49 \\
\hline Індія & 1065 & Португалія & 47 \\
\hline Японія & 927 & Нова Зеландія & 39 \\
\hline Pociя & 887 & Нігерія & 24 \\
\hline Світ & 21190 & Україна & 128 \\
\hline
\end{tabular}

Ще одним вагомим показником у сталому розвитку країн світу є рівень та інтенсивність викидів вуглекислого газу. На рис. 8 та 9 показано динаміку величини викидів вуглекислого газу в атмосферу.

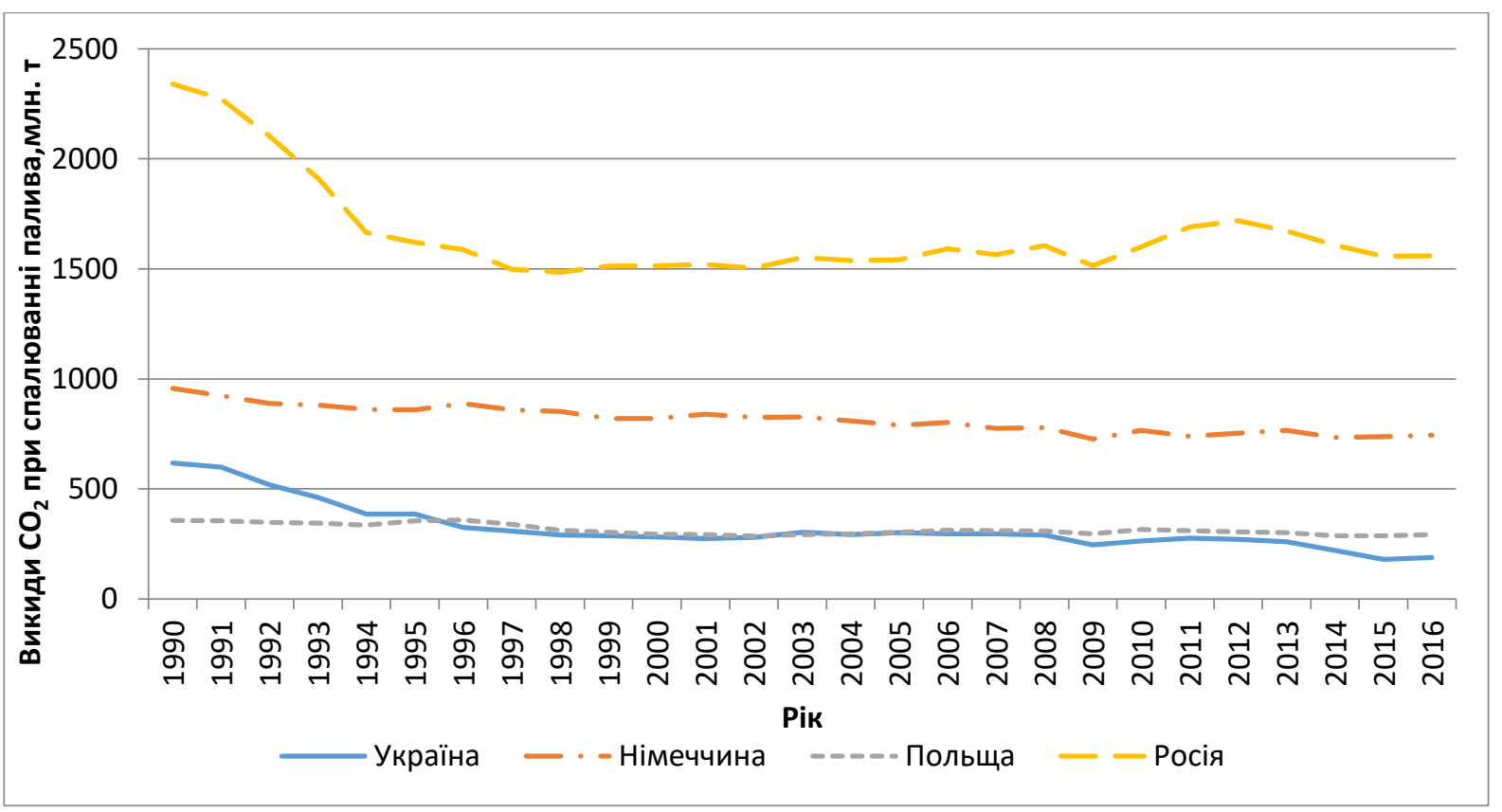

Рисунок 8 - Викиди $\mathrm{CO}_{2}$ при спалюванні палива (млн. т) України у порівнянні з Німеччиною, Польщею та Росією 


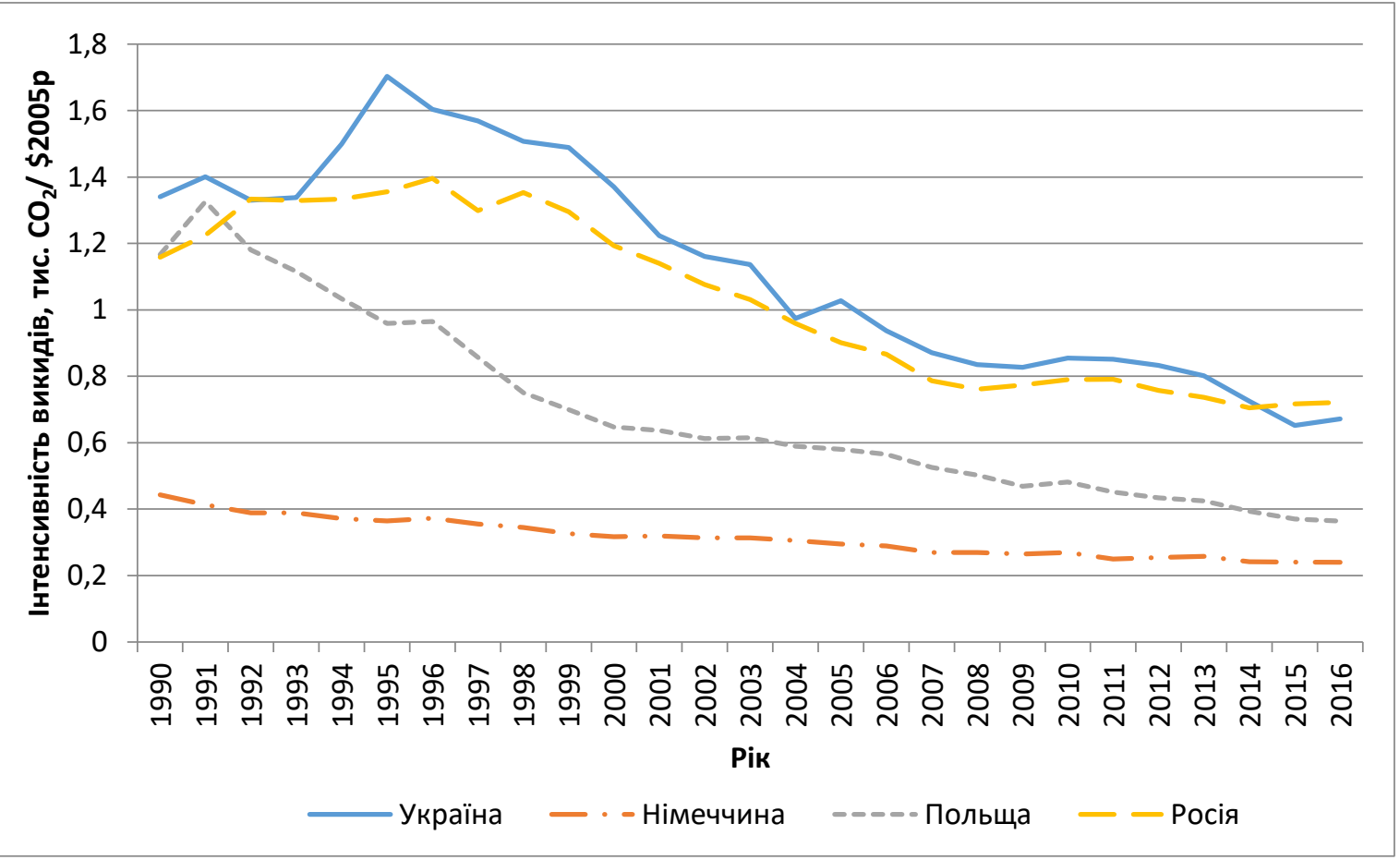

Рисунок 9 - Інтенсивність викидів $\mathrm{CO}_{2}$ України у порівнянні з Німеччиною, Польщею та Росією

На сьогоднішній день рівень інтенсивності викидів вуглекислого газу в Україні залишається одним із найвищих світі (див. табл. 11), що пояснюється високим рівнем енергоємності виробництва та низьким рівнем ВВП в Україні.

Таблиця 11 - Рейтинг країн світу за обсягами викидів вуглекислого гузу в навколишнє середовище

\begin{tabular}{|l|l|l|l|}
\hline \multicolumn{3}{|l|}{ Викиди $\mathrm{CO}_{2}$, млн. т $\mathrm{CO}_{2}$} & \multicolumn{2}{l|}{ Остання п’ятірка } \\
\hline \multicolumn{2}{|l|}{ Перша п’ятірка } & 8796 & Нігерія \\
\hline Китай & 5112 & Португалія & 49 \\
\hline США & 2088 & Швеція & 42 \\
\hline Індія & 1560 & Норвегія & 38 \\
\hline Росія & 1096 & Нова Зеландія & 33 \\
\hline Японія & 31565 & Україна & 189 \\
\hline Світ & & Остання п’ятірка & \\
\hline Інтенсивність викидів $\mathrm{CO}_{2}$, кг СО $/ \$ 2005 p$. & Франція & 0,148 \\
\hline Перша п’ятірка & 0,722 & Норвегія & 0,136 \\
\hline Росія & 0,720 & Колумбія & 0,109 \\
\hline ПАР & 0,672 & Швеція & 0,098 \\
\hline Україна & 0,604 & Нігерія & 0,044 \\
\hline Казахстан & 0,596 & Україна & 0,672 \\
\hline Узбекистан & 0,324 & & \\
\hline Світ & & & \\
\hline
\end{tabular}

Нижче в табл. 12 та 13 наведено дані, які характеризують енергетичний сектор економіки України у сфері видобутку та споживання енергетичних ресурсів порівняню з країнами, які займають вищі та нижчі ступені за різними показниками (наведено перша та остання п'ятірки із виділенням загальносвітового показника та України). Представлені показники свідчать про значний невикорисаний потенціал паливноенергетичного комплексу нашої країни. 
ISSN 1813-5420 (Print). Енергетика: економіка, технології, екологія. 2017. № 3

Таблиця 12- Рейтинг країн світу за рівнем виробництва паливно-енергетичних ресурсів

\begin{tabular}{|c|c|c|c|}
\hline \multicolumn{4}{|c|}{ Виробництво непереробленої нафти, млн. т } \\
\hline \multicolumn{2}{|l|}{ Перша п’ятірка } & \multicolumn{2}{|l|}{ Остання п’ятірка } \\
\hline Саудівська Аравія & 598 & Іспанія & 0,14 \\
\hline США & 556 & Португалія & 0,07 \\
\hline Росія & 547 & Тайвань & 0,01 \\
\hline Канада & 219 & Швеція & 0 \\
\hline Китай & 202 & Бельгія & 0 \\
\hline Світ & 4359 & Україна & 2 \\
\hline \multicolumn{4}{|c|}{ Виробництво нафтопродуктів, млн. т } \\
\hline \multicolumn{2}{|l|}{ Перша п’ятірка } & \multicolumn{2}{|l|}{ Остання п’ятірка } \\
\hline США & 867 & Нова Зеландія & 6 \\
\hline Китай & 539 & Чехія & 6 \\
\hline Росія & 276 & Узбекистан & 3 \\
\hline Індія & 248 & Нігерія & 2 \\
\hline Саудівська Аравія & 173 & Україна & 0,69 \\
\hline Світ & 4226 & Україна & 0,69 \\
\hline \multicolumn{4}{|c|}{ Виробництво природного газу, млрд. м $^{3}$} \\
\hline \multicolumn{2}{|l|}{ Перша п’ятірка } & \multicolumn{2}{|l|}{ Остання п’ятірка } \\
\hline США & 750 & Південна Корея & 0,15 \\
\hline Росія & 628 & Іспанія & 0,05 \\
\hline Іран & 190 & Франція & 0,03 \\
\hline Катар & 167 & Швеція & 0 \\
\hline Канада & 165 & Бельгія & 0 \\
\hline Світ & 3579 & Україна & 20 \\
\hline \multicolumn{4}{|c|}{ Виробництво вугілля, млн. т } \\
\hline \multicolumn{2}{|l|}{ Перша п’ятірка } & \multicolumn{2}{|l|}{ Остання п’ятірка } \\
\hline Китай & 3210 & Алжир & 0 \\
\hline Індія & 708 & Тайвань & 0 \\
\hline США & 683 & Японія & 0 \\
\hline Австралія & 509 & Португалія & 0 \\
\hline Індонезія & 459 & Нідерланди & 0 \\
\hline Світ & 7289 & Україна & 36 \\
\hline \multicolumn{4}{|c|}{ Частка ВДЕ у виробництві електроенергії, \% } \\
\hline \multicolumn{2}{|l|}{ Перша п'ятірка } & \multicolumn{2}{|l|}{ Остання п’ятірка } \\
\hline Норвегія & 97,9 & Південна Корея & 2,3 \\
\hline Нова Зеландія & 84 & Алжир & 0,27 \\
\hline Колумбія & 82 & OAE & 0,23 \\
\hline Бразилія & 81,2 & $\begin{array}{l}\text { Саудівська } \\
\text { Аравія }\end{array}$ & 0 \\
\hline Канада & 66,4 & Кувейт & 0 \\
\hline Світ & 24,38 & Україна & 6,5 \\
\hline
\end{tabular}


ISSN 1813-5420 (Print). Енергетика: економіка, технологіï, екологія. 2017. № 3

Таблиця 13 - Рейтинг країн світу за рівнем споживання паливно-енергетичних ресурсів

\begin{tabular}{|c|c|c|c|}
\hline \multicolumn{4}{|c|}{ Споживання непереробленої нафти, млн. т } \\
\hline \multicolumn{2}{|c|}{ Перша п’ятірка } & \multicolumn{2}{|l|}{ Остання п’ятірка } \\
\hline США & 840 & Чехія & 6 \\
\hline Китай & 563 & Нова Зеландія & 6 \\
\hline Росія & 286 & Узбекистан & 3 \\
\hline Індія & 249 & Нігерія & 2 \\
\hline Японія & 165 & Україна & 0,66 \\
\hline Світ & 4182 & Україна & 0,66 \\
\hline \multicolumn{4}{|c|}{ Споживання нафтопродуктів, млн. т } \\
\hline \multicolumn{2}{|c|}{ Перша п’ятірка } & \multicolumn{2}{|l|}{ Остання п’ятірка } \\
\hline США & 771 & Португалія & 9 \\
\hline Китай & 520 & Норвегія & 9 \\
\hline Індія & 203 & Чехія & 8 \\
\hline Японія & 167 & Нова Зеландія & 7 \\
\hline Росія & 149 & Узбекистан & 2 \\
\hline Світ & 4194 & Україна & 11 \\
\hline \multicolumn{4}{|c|}{ Споживання природного газу, млрд. м ${ }^{3}$} \\
\hline \multicolumn{2}{|l|}{ Перша п’ятірка } & \multicolumn{2}{|l|}{ Остання п’ятірка } \\
\hline США & 782 & Нова Зеландія & 5 \\
\hline Росія & 423 & Португалія & 5 \\
\hline Китай & 203 & ПАР & 5 \\
\hline Іран & 188 & Чілі & 5 \\
\hline Японія & 127 & Швеція & 1 \\
\hline Світ & 3629 & Україна & 31 \\
\hline \multicolumn{4}{|c|}{ Споживання вугілля, млн. т } \\
\hline \multicolumn{2}{|l|}{ Перша п’ятірка } & \multicolumn{2}{|l|}{ Остання п’ятірка } \\
\hline Китай & 3546 & Алжир & 0,2 \\
\hline Індія & 922 & Венесуела & 0,09 \\
\hline США & 661 & Нігерія & 0,04 \\
\hline Німеччина & 226 & Кувейт & 0 \\
\hline Росія & 210 & Саудівська Аравія & 0 \\
\hline Світ & 7421 & Україна & 55 \\
\hline \multicolumn{4}{|c|}{ Частка вітрової та сонячної енергії у виробництві електроенергії, \% } \\
\hline \multicolumn{2}{|l|}{ Перша п’ятірка } & \multicolumn{2}{|l|}{ Остання п’ятірка } \\
\hline Нова Зеландія & 23,5 & Саудівська Аравія & 0 \\
\hline Іспанія & 23,5 & Узбекистан & 0 \\
\hline Португалія & 22,3 & Кувейт & 0 \\
\hline Німеччина & 18 & Нігерія & 0 \\
\hline Італія & 16,5 & Венесуела & 0 \\
\hline Світ & 5,66 & Україна & 0,82 \\
\hline
\end{tabular}


ISSN 1813-5420 (Print). Енергетика: економіка, технологіï, екологія. 2017. № 3

\section{Аналіз розвитку енергетики України за даними World Development Indicators}

Ще одним важливим критерієм є оцінки світового розвитку World Development Indicators. Згідно даних World Development Indicators за 2017 р. для характеристики енергетики України розглядатимемо оцінки, наведеними у кластері «Навколишнього середовища» [17]. Проаналізовано дані щодо України у 2016 р. у порівнянні $з$ даними Німеччини, Польщі та Європи і Центральної Азії: табл. 14 - виробництво та використання електроенергії; табл. 15 - виробництво електроенергії, джерела та доступ до електроенергії; табл. 16 - енергетична залежність, енергоефективність та викиди вуглецю; табл. 17 - стала енергія для всіх (доступ та споживання ВДЕ). Дані Світового Банку також підтверджують необхідність зміни структури паливно-енергетичного балансу України. Розвиток еергетичного мектора економіки України відбувається темпами, які не дозволяють виконати намічені планові показники, наведені в проаналізованих вище українських директивних документах.

Таблиця 14 - Порівняння країн за рівнем виробництва та використання електроенергії

\begin{tabular}{|l|c|c|c|c|}
\hline & Україна & Німеччина & Польща & $\begin{array}{c}\text { Європа і Цент. } \\
\text { Азія }\end{array}$ \\
\hline $\begin{array}{l}\text { Виробництво енергії, млн. т } \\
\text { н.е. }\end{array}$ & 86,3 & 120,4 & 70,9 & 3831,7 \\
\hline $\begin{array}{l}\text { Споживання енергії, млн. т } \\
\text { н.е. }\end{array}$ & 116,1 & 317,7 & 97,6 & 4625,4 \\
\hline $\begin{array}{l}\text { Використання викопного } \\
\text { палива, \% }\end{array}$ & 78,2 & 81,1 & 91,1 & 79,1 \\
\hline Горючі ВДЕ і відходи, \% & 1,6 & 8,7 & 8,5 & 5,6 \\
\hline $\begin{array}{l}\text { Альтернативна та ядерна } \\
\text { енергія \% }\end{array}$ & 19,9 & 11,1 & 0,8 & 14,8 \\
\hline $\begin{array}{l}\text { Зростання використання } \\
\text { енергії 1990-2013 р. \% }\end{array}$ & $-2,5$ & $-0,4$ & $-0,2$ & 0 \\
\hline
\end{tabular}

Таблиця 15 - Порівняння країн за балансом виробництва електроенергії

\begin{tabular}{|l|c|c|c|c|}
\hline & Україна & Німеччина & Польща & $\begin{array}{c}\text { Свропа і Цент. } \\
\text { Азія }\end{array}$ \\
\hline $\begin{array}{l}\text { Виробництво } \\
\text { електроенергії } \\
\text { кВтггд }\end{array}$ млрд. & 193,7 & 632,9 & 164 & 5321,8 \\
\hline Джерела електроенергії у \% від загального виробництва & & \\
\hline - вугілля & 41,8 & 47,2 & 85,2 & 25,3 \\
\hline -природний газ & 7,2 & 10,9 & 3,2 & 24,4 \\
\hline -нафта & 0,2 & 1,1 & 1,1 & 1,3 \\
\hline -енергія води & 7,1 & 3,6 & 1,5 & 16,8 \\
\hline -ВДЕ & 0,7 & 20,4 & 8,9 & 9,5 \\
\hline -ядерна енергія & 43 & 15,4 & 100 & 100 \\
\hline $\begin{array}{l}\text { Доступ до електроенергії, } \\
\text { \% }\end{array}$ & 100 & 100 & & \\
\hline
\end{tabular}

Таблиця 16 - Порівняння країн за балансом виробництва електроенергії

\begin{tabular}{|l|c|c|c|c|}
\hline & Україна & Німеччина & Польща & $\begin{array}{c}\text { Європа і Цент. } \\
\text { Азія }\end{array}$ \\
\hline Мережевий імпорт енергії, \% & 27 & 61 & 28 & 17 \\
\hline Енергоефективність, \$/к.н.е. & 3,4 & 11,5 & 9,8 & 9,1 \\
\hline Загальні викиди СО 2, млн. т & 271101 & 757313 & 302333 & 6551554 \\
\hline $\begin{array}{l}\text { Інтенсивність вуглецю, } \\
\text { кг/к.н.е }\end{array}$ & 2,3 & 2,4 & 3,1 & 2,3 \\
\hline
\end{tabular}


ISSN 1813-5420 (Print). Енергетика: економіка, технологіï, екологія. 2017. № 3

Таблиця 17 - Порівняння країн за доступом до нетвердих джерел палива та використання ВДЕ

\begin{tabular}{|l|c|c|c|c|}
\hline & Україна & Німеччина & Польща & $\begin{array}{c}\text { Європа і Цент. } \\
\text { Азія }\end{array}$ \\
\hline $\begin{array}{l}\text { Доступ сільського населення } \\
\text { до не твердих палив, \% }\end{array}$ & 100 & 100 & 100 & 100 \\
\hline $\begin{array}{l}\text { Споживання відновлювальної } \\
\text { енергії, \% }\end{array}$ & 2,9 & 12 & 10,9 & 18,5 \\
\hline $\begin{array}{l}\text { Виробництво відновлювальної } \\
\text { електроенергії, \% }\end{array}$ & 5,7 & 23 & 10,4 & 20,9 \\
\hline
\end{tabular}

\section{Аналіз за даними World Economic Forum}

Світовий економічний форум дозволяє оцінити стан енергетики за допомогою формування Global Energy Architecture Performance Index [21]. Станом на 2017 рік Україна займає 73 місце у загальному рейтингу, покращивши свої позиції на 4 місця, 3 наступними показниками: економічне зростання i розвиток - 0,3; екологічна стійкість - 0,65; енергетичний доступ і безпека $-0,79$.

Для оцінки становища України порівняємо ії̈ з показниками інших країн (див. табл. 18):

Таблиця 18 - Порівняння країн за даними World Economic Forum (Global Energy Architecture Performance Index)

\begin{tabular}{|l|l|l|l|l|}
\hline & \multicolumn{1}{|c|}{ Позиція } & \multicolumn{1}{|c|}{$\begin{array}{c}\text { Економічне } \\
\text { сростання i } \\
\text { розвиток }\end{array}$} & $\begin{array}{c}\text { Екологічна } \\
\text { стійкість }\end{array}$ & $\begin{array}{c}\text { Енергетичний } \\
\text { доступ і безпека }\end{array}$ \\
\hline Швейцарія & 1 & 0,74 & 0,77 & 0,88 \\
\hline Норвегія & 2 & 0,67 & 0,75 & 0,88 \\
\hline Швеція & 3 & 0,63 & 0,8 & 0,9 \\
\hline Данія & 4 & 0,69 & 0,71 & 0,91 \\
\hline Франція & 5 & 0,62 & 0,81 & 0,88 \\
\hline Австрія & 6 & 0,67 & 0,74 & 0,88 \\
\hline Іспанія & 7 & 0,65 & 0,73 & 0,87 \\
\hline Колумбія & 8 & 0,73 & 0,68 & 0,83 \\
\hline Нова Зеландія & 9 & 0,59 & 0,75 & 0,9 \\
\hline Уругвай & 10 & 0,63 & 0,73 & 0,85 \\
\hline Німеччина & 19 & 0,62 & 0,64 & 0,88 \\
\hline Польща & 37 & 0,66 & 0,56 & 0,8 \\
\hline Росія & 48 & 0,55 & 0,6 & 0,8 \\
\hline Україна & $\mathbf{7 3}$ & $\mathbf{0 , 3}$ & $\mathbf{0 , 6 5}$ & $\mathbf{0 , 7 9}$ \\
\hline
\end{tabular}

За даними World Economic Forum складною проблемою України є значення такого показника, як економічне зростання і розвиток. Зазначимо, що до економічної складової відносяться інтенсивність використання енергії, рівень експорту та імпорту енергоносіїв та ціни на енергоносії для промисловості та населення внаслідок оподаткування та субсидій.

\section{Висновки}

1. В Україні слід врахувати, що нова економіка майбутнього - це не поступальний розвиток старої промисловості, що базується переважно на силових енергетичних процесах, а неоіндустріалізація, заснована на поєднанні великих установок і розосередженої генерації, силових та інформаційних процесів, фізичних та інтелектуальних систем. На зміну індустріальній енергетичній цивілізації, пов'язаної 3 використанням переважно силових процесів, приходить новий енергоінформаційний електричний світ, заснований на широкому використанні інтелектуальних соціо-фізичних систем. Енергоінформаційні системи, крім утилітарного якісного енергозабезпечення, створюють і нову якість життя.

2. Одним із основних недоліків України є відсутність дієвої комплексної енергетичної політики, а також низький рівень використання ВДЕ та висока залежність від вугілля, природного газу та ядерної енергії як первинних джерел енергії. при цьому слід враховувати, що вплив окремих негативних факторів буде зростати. Так, на початку 2019 року Україна опиниться перед загрозою потужного удару по власній енергетичній безпеці у зв'язку із завершенням чинних газових контрактів з Росією.

3. Україна має видобудувати сучасну систему розвитку власної енергетики, виходячи 3 пріоритетності національних інтересів та покладаючись максимально на власні сили. Для покращення 
економічної складової необхідно зменшити рівень використання імпортних енергоносіїв, особливо імпорт природного газу, а також звернути увагу на екологічну стійкість України. Використання ВДЕ впливає не тільки на екологічний аспект енергетики, вплив на економічну та енергетичну безпеку є суттєвим.

4. Потрібні ефективні реформи у таких сферах як газова та нафтова галузі, нафтопереробка, електроенергетика, підтримка енергоефективності та використання ВДЕ. Практично відсутній процес широкого стимулювання залучення місцевої влади до фінансування енергоефективних проектів та ініціатив (натомість стрімко зростає сума державних субсидій, що демотивує громадян займатися скороченням енергоспоживання). Скорочення енергоспоживання за рахунок енергоефективності та енергозбереження, розвиток використання ВДЕ сприятимуть суттєвому зменшенню використання викопних видів палив в Україні до 2050 року та скороченню викидів ПГ. Україні важливо виконати ціль щодо скорочення викидів ПГ та сприяти досягненню глобальної цілі щодо недопущення збільшення температури на Землі більш ніж на $2{ }^{\circ} \mathrm{C}$ до 2100 року.

\section{Список використаної літератури}

1. Давуд Р. Устойчивая энергетика - это "золотая нить" - генсек ООН //17 Сентябрь 2015. www.un.org/russian/news/story.asp?NewsID=24454.

2. Денисюк С.П. Формування політики підвищення енергетичної ефективності - сучасні виклики та європейські орієнтири // Енергетика: економіка, технології, екологія. - 2013. - №2 . - С. 7-22.

3. Енергоефективність та відновлювані джерела енергії / Під заг. ред. А.К. Шидловського; Авт.: Бевз С.М., Бондаренко Б.І., Денисюк С.П. та інш. - К.: Українські енциклопедичні знання, 2007. - 500 с.

4. Зорина Т.Г. Устойчивое развитие энергетики: сущность и методические подходы к оценке // Современные технологии управления. ISSN 2226-9339. - №1 (49). № статьи: 4905. Дата публикации: $2015-$ 01-08. Режим доступа: http://sovman.ru/article/4905/

5. Мировой Энергетический Совет [Электронный ресурс] / Мировой Энергетический Совет 2013. Режим доступа: http://www.worldenergy.org/wp-content/uploads/2014/04/ WEC_16_page_document_21_3_14_RU_FINAL.pdf. - Дата доступа: 04.12.2014.

6. Форсайт та побудова стратегії соціально-економічного розвитку України на середньостроковому (до 2020 року) і довгостроковому (до 2030 року) часових горизонтах / наук. керівник проекту акад. НАН України М. З.Згуровський. - К.: НТУУ «КПІ імені Ігоря Сікорського», Вид-во «Політехніка», 2016. - 184 c.

7. Цілі Розвитку Тисячоліття Україна: 2000-2015. Національна доповідь. - К.: Проект «Прискорення прогресу у досягненні Цілей Розвитку Тисячоліття в Україні», 2015. - 124 с.

8. Цілі Сталого Розвитку: Україна. Національна доповідь. - К.: Міністерство економічного розвитку і торгівлі України, 2017. - 174 с.

9. Энергетика и устойчивое развитие [Электронный ресурс] // Бюллетень МАГАТЭ 54-1-Март 2013. Режим доступа: http://www.iaea.org/Publications /Magazines/Bulletin/ Bull541/ Russian/Bull54_1_Mar2013_ru.pdf. - Дата доступа: 27.10.2014.

10. Action Plan for Energy Efficiency: Realising the Potential. COM (2006) 545 final / Commission of the European Communities, Brussels, 19.10.2006. - 25 p.

11. An Energy Policy for Europe: Communication from the Commission to the European Council and the European Parliament: Doc. COM (2007) 1 final, Brussels, 10.01.2007 [Electronic resource] // EUR-Lex. Access to European Union law. - Mode of access: <http://eur-lex.europa.eu/smartapi/cgi / sga_doc?smartapi!celexplus! prod!DocNumber\&lg =en\&type_doc=COMfinal \&an_doc=2007\&nu_doc=1>.

12. Climate Science Special Report. Fourth National Climate Assessment. Volume I. - U.S. Global Change Research Program, 2017. - 477 p.

13. Denysiuk S. Green Industrial Development in Ukraine / S. Denysiuk, L. Galperina // Industrial Policy and Sustainable Growth. Editors: Murat Yülek. - Springer. - 26 p. ISBN: 978-981-10-3964-5 (Print), 978-98110-3964-5 (Online).

14. Enerdata. Yearbook 2016 [Електронний ресурc]. https://yearbook.enerdata.net

15. Energy 2020. A strategy for competitive, sustainable and secure energy: Communication from the Commission to the European Parliament, the Council, the European Economic and Social Committee and the Committee of the Regions: Doc. COM (2010) 639 final. Brussels, 10.11.2010 [Electronic resource] // EUR-Lex. Access to European Union law. - Mode of access: <http://eurlex.europa.eu/LexUriServ/LexUriServ.do?uri=COM:2010:0639:FIN:EN:PDF>.

16. Sustainable Energy For All Global Tracking Framework. Progress toward Sustainable Energy 2017. The World Bank and the International Energy Agency. - Publishing and Knowledge Division, The World Bank, (1818 H Street NW, Washington, USA), 2017. - 44 p.

17. The World Bank. World Development Indicators [Електронний pecypc]. http://wdi.worldbank.org/tables

18. The World Energy Issues Monitor 2017. - London: World Energy Council, 2017. - 156 p. 
19. World Energy Council. Energy Trillema Index [Електронний pecypc]. https://trilemma.worldenergy.org

20. World Energy Council. Full report: Energy efficiency - a straight path towards energy sustainability [Text].

21. World Energy Forum. Global Energy Architecture Performance Index Report 2017 [Text]

22. World Energy Trilemma: Time to get real - the agenda for change [Electronic resource] / World Energy Council. - Mode of access: http://www.worldenergy.org. - Date of access: 02.12.2014.

23. https://news.rambler.ru/economics/37005093/?utm_content=rnews\& utm_ medium $=\mathrm{read}_{-}$ more\&utm_source=copylink

S. Denysiuk, Dr. Sc. Sciences., Prof. ORCID 0000-0002-6299-3680

V. Tarhonskyi, Msc. ORCID 0000-0003-3801-8284

National Technical University of Ukraine "Igor Sikorsky Kyiv Polytechnic Institute" SUSTAINABLE DEVELOPMENT OF UKRAINE'S ENERGY IN THE WORLD MEASURES

In the article are considered the features of the sustainable development of the world power industry, the characteristics of the "Sustainable Energy for All" initiative (SEforAll) are given. An estimation of the influence of development of the energy industry on the sustainable development of the economy as a whole and on climate change under the provisions of the Paris Climate Agreement is given. To assess the directions of Ukraine's energy development in the twenty-first century. European benchmarks are presented. The state of fulfillment of the requirements of sustainable development in the Ukrainian fuel and energy sector in accordance with the purpose of sustainable development No. 7 and the main tasks of the national policy documents is analyzed in detail.

To analyze the prospects for the development of the national fuel and energy sector, the indicators of energy trilemma (energy security, energy equality, environmental sustainability), proposed by CEE, for Ukraine and individual countries of the world have been analyzed. According to the data of the World Bank Enerdata Yearbook, in particular, the dynamics of changes in energy intensity, consumption and energy production in 1990-2016, as well as according to World Development Indicators 2016 in Ukraine, the comparison of the indicators of Ukraine and individual countries was carried out for the complex characterization of the separate sectors of the fuel and energy complex of Ukraine. The status of Ukraine according to the results of 2016 has been characterized according to the World Economic Forum according to the Global Energy Architecture Performance Index by indicators such as economic growth and development, environmental sustainability, energy access and security.

Keywords: Sustainable Development, Energetics for All, Energy Trilemma, Energy Consumption, Consumption and Energy Production, Enerdata Yearbook, Global Energy Architecture Performance Index.

\section{References}

1. R. Dawood . Sustainable energy is the "golden thread" - the UN Secretary General //17 September 2015. - www.un.org/russian/news/story.asp?NewsID=24454.

2. S. Denysiuk. Policy formation increase energy efficiency - current challenges guidelines and European// Power engineering: economics, technique, ecology. - 2013. - №2. - p. 7-22.

3. Enerhoefektyvnist ta vidnovliuvani dzherela enerhii / Pid zah. red. A.K. Shydlovskoho; Avt.: Bevz S.M., Bondarenko B.I., Denysiuk S.P. ta insh. - K.: Ukrainski entsyklopedychni znannia, 2007. - 500 c.

4. T.Zorina. Steady development of energy : essence and methodical going near an estimation // Modern technologies of management. ISSN 2226-9339. - №1 (49). № : 4905. Publication data: 2015-01-08. Access mode: http://sovman.ru/article/4905/

5. World Energy Council 2013. - Access mode: http://www.worldenergy.org/wp-content/uploads/2014/04/ WEC_16_page_document_21_3_14_RU_FINAL.pdf. - Acces data: 04.12.2014.

6. Forsait ta pobudova stratehii sotsialno-ekonomichnoho rozvytku Ukrainy na serednostrokovomu (do 2020 roku) i dovhostrokovomu (do 2030 roku) chasovykh horyzontakh / nauk. kerivnyk proektu akad. NAN Ukrainy M.Zghurovskyi. - K.: NTUU «KPI imeni Ihoria Sikorskoho», Vyd-vo «Politekhnika», 2016. - p. 184 .

7. Tsili Rozvytku Tysiacholittia Ukraina: 2000-2015. Natsionalna dopovid. - K.: Proekt «Pryskorennia prohresu u dosiahnenni Tsilei Rozvytku Tysiacholittia v Ukraini», 2015. - p.124 .

8. Sustainable Development Goals: National report. - K.: Ministry of Economic Development and Trade of Ukraine, 2017. - p.174.

9. Power engineering and Sustainable development [Electronic resourse] // IAEA Bulletin 54-1-March 2013. - Access mode: http://www.iaea.org/Publications /Magazines/Bulletin/ Bull541/ Russian/Bull54_1_Mar2013_ru.pdf. - Acces data: 27.10.2014.

10. Action Plan for Energy Efficiency: Realising the Potential. COM (2006) 545 final / Commission of the European Communities, Brussels, 19.10.2006. - 25 p.

11. An Energy Policy for Europe: Communication from the Commission to the European Council and the European Parliament: Doc. COM (2007) 1 final, Brussels, 10.01.2007 [Electronic resource] // EUR-Lex. Access 
to European Union law. - Mode of access: <http://eur-lex.europa.eu/smartapi/cgi / sga_doc?smartapi!celexplus! prod!DocNumber\&lg $=$ en\&type_doc $=$ COMfinal \&an_doc $=2007 \& n u \_d o c=1>$.

12. Climate Science Special Report. Fourth National Climate Assessment. Volume I. - U.S. Global Change Research Program, 2017. - 477 p.

13. Denysiuk S. Green Industrial Development in Ukraine / S. Denysiuk, L. Galperina // Industrial Policy and Sustainable Growth. Editors: Murat Yülek. - Springer. - 26 p. ISBN: 978-981-10-3964-5 (Print), 978-98110-3964-5 (Online).

14. Enerdata. Yearbook 2016 [Electronic resourse]. https://yearbook.enerdata.net

15. Energy 2020. A strategy for competitive, sustainable and secure energy: Communication from the Commission to the European Parliament, the Council, the European Economic and Social Committee and the Committee of the Regions: Doc. COM (2010) 639 final. Brussels, 10.11.2010 [Electronic resource] // EUR-Lex. Access to European Union law. - Mode of access: <http://eurlex.europa.eu/LexUriServ/LexUriServ.do?uri=COM:2010:0639:FIN:EN:PDF>.

16. Sustainable Energy For All Global Tracking Framework. Progress toward Sustainable Energy 2017. The World Bank and the International Energy Agency. - Publishing and Knowledge Division, The World Bank, (1818 H Street NW, Washington, USA), 2017. - 44 p.

17. The World Bank. World Development Indicators [Електронний pecypc]. http://wdi.worldbank.org/tables

18. The World Energy Issues Monitor 2017. - London: World Energy Council, 2017. - 156 p.

19. World Energy Council. Energy Trillema Index [Електронний pecypc]. https://trilemma.worldenergy.org [Text].

20. World Energy Council. Full report: Energy efficiency - a straight path towards energy sustainability

21. World Energy Forum. Global Energy Architecture Performance Index Report 2017 [Text]

22. World Energy Trilemma: Time to get real - the agenda for change [Electronic resource] / World Energy Council. - Mode of access: http://www.worldenergy.org. - Date of access: 02.12.2014.

23. https://news.rambler.ru/economics/37005093/?utm_content=rnews\& utm_ medium= read more\&utm_source=copylink 